\title{
Sustainability Practices and Banks Financial Performance: A Conceptual Review from the Islamic Banking Industry in Malaysia
}

\author{
Amin Jan ${ }^{1}$, Maran Marimuthu ${ }^{1}$, Muhammad Pisol bin@Mohd Mat Isa ${ }^{1} \&$ Pia A. Albinsson ${ }^{2}$ \\ ${ }^{1}$ Department of Management and Humanities, Universiti Teknologi PETRONAS, Malaysia \\ ${ }^{2}$ Walker College of Business Appalachian State University, United States \\ Correspondence: Amin Jan, Department of Management and Humanities, Universiti Teknologi PETRONAS, \\ Malaysia. E-mail: amin_jan_khan@yahoo.com
}

Received: September 2, 2018

doi:10.5539/ijbm.v13n11p61
Accepted: September 30, 2018

Online Published: October 12, 2018

\begin{abstract}
This paper aims to propose a framework for measuring sustainability practices of the Islamic banking industry in Malaysia. Sustainability practicing and reporting has received limited attention in the Islamic banking literature. The frameworks used for measuring sustainability practices are also found inadequate. This study transformed the Global Reporting Initiative's GRI sustainability measurement framework in light of Shariah principles to make it compatible for measuring sustainability practices in the Islamic banking industry. The posited framework illuminates the positive theoretical relationship between sustainability practices and banks financial performance from the Islamic perspective. This study lends credence to the Islamic Reporting Initiative IRI envisioned framework of building an international standard sustainability measurement framework for the Islamic banking industry in future. This study may also serve as a launching pad in the process of developing an international standards sustainability measurements framework for the Islamic banking industry in the world.
\end{abstract}

Keywords: sustainability practices, Islamic banking, banks financial performance, Maqasid-Al-Shariah

\section{Introduction}

The terms corporate sustainability and sustainable development was first defined in the Brundtland report (Brundtland, 1987). That report coined and defined the meaning of sustainable development as the process of economic growth, environmental protection, and social equality. Sustainability in the business field refers to the process by which companies manage their economic, social and environmental risks, obligations and opportunities. These three impacts are sometimes referred to as profits, people and planet. Sustainability practices become a vital subject for many corporations due to the increasing public awareness about the impact of business on society and environment (Zainal and Zainuddin, 2013). This analogy led some companies towards obtaining a social license (Gunningham et al., 2004), and it also stimulated an increase in the number of sustainability practices by firms globally. In year 2004 less than 50 percent of the world's largest 250 companies issued their sustainability reports. While in 2008,80 percent of them published sustainability reports (KPMG, 2008). This trend shows that sustainability practicing is becoming obligatory (Jan et al., 2017). Excellent organizations are expected to be in an advanced state of social responsiveness, through proactive corporate sustainability practicing and reporting (Amran et al., 2017). This increase in sustainability practicing and reporting leaves little doubt as to why many researchers are actively examining business sustainability (Zainal and Zainuddin, 2013). Inline of the growing need and research on business sustainability, studies found that sustainability practicing and reporting from the Islamic banking industry around the world is still low. Meutia and Febrianti (2017), found the level of sustainability disclosures of Indonesian and Malaysian Islamic banks with only 26 percent. Nobanee and Ellili (2016), found sustainability disclosures of the Islamic banks very low as compared to the conventional banks in United Arab Emirates UAE. Belal et al. (2015), argued that the Islamic banks in Bangladesh failed to provide full sustainability disclosures. Mallin et al. (2014), conducted a study on 91 Islamic banks across 13 countries and found that Islamic banks in these countries paid less attention to the voluntary sustainabiity practices and disclosures. Yusoff and Darus (2014), ealluded that the environmental sustainability practices and disclosures of the Islamic financial institution in Malaysia were minimal. Ahmed Haji and Anum Mohd Ghazali (2013), found the quality of voluntary sustainability practices and disclosures of the Shariah-compliant companies in Malaysia as very low. Farook et al. (2011), reported that sustainabiity 
practices and disclousers of 14 Islamic banks from 14 different countries were ineffient. Hassan and Syafri Harahap (2010), explored sustainability practices and reporting of Islamic banks from 7 Muslim countries and found that sustainability practicies and reporting was not of a major concern to the Islamic banks of these countries.

In general, the banking industry has responded slowly to the modern concept of sustainability and the associated global challenges (Jeucken, 2002). The financial crisis of 2007-2008 and the failure of large world banks brought the issue of banking sustainability into the global spotlight (Hashem et al., 2016). In the initial phase, most of the research was conducted on the economic dimension of sustainability only. Jan and Marimuthu (2016), explained the economic role of the banking industry and proposed methods for measuring economic sustainability of the Islamic banks. As research on banks' economic sustainability dimension advanced, it started to highlight the associated unfavourable social and environmental effects. Saleem et al. (2013), illuminated that while preserving its economic sustainability the banking industries have overshadowed the negative impacts of their operations on the environment and the society in general. The banking industries are contributing towards the economic growth, but their activities may have a negative impact on the environment and societies(Saleem et al., 2013). As a result of such inefficient sustainability policies of the firms, the global world is not achieving its set milestones of social and environmental sustainability (Sobhani et al., 2011).

According to the global risks reports 2017 and 2018, published by world economic forum, the current top two global risks in terms of likelihood are sustainabiliy risks (Forum, 2017, Forum, 2018). To cater sustainability risks the United Nation UN launched UN Sustainable Development Goals SDG program which is formally known as "transforming our world: the 2030 agenda for sustainable development. According to the SDGs, corporations are required to strategize about the factors such as reducing carbon $\mathrm{C} 02$ emission, initiating green products, promoting biodiversity, reducing poverty in the society, improving education and public health, human rights, decent labour practices in their corporate business strategies. In line with that many firms have linked up their business policies to the UN-SDGs. These efforts clearly show how big and serious is the issue of sustainability at the world stage. When it comes to the Islamic banking industry specifically, the literature suggests that the studies related to sustainability of the Islamic banking industry are widely over-sighted. For instance, the performance of the Islamic banking industry is studied from a variety of angles such as the profitability determinants of Islamic banks (Hassan and Bashir, 2003). Liquidity risk management in the Islamic banking industry (Ismal, 2010). Insolvency risk management in Islamic banks (Čihák and Hesse, 2010). Productivity and efficiency of Islamic banking (El Moussawi and Obeid, 2011). Technical efficiency of Islamic banking (Sufian, 2007). Foreign vs. domestic Islamic bank performance (Muda et al., 2013). Islamic vs. Conventional bank performance (Qureshi and Shaikh, 2012). The role of Islamic banking in the financial crisis (Said, 2013). Comparison among Islamic banks (Saleh and Zeitun, 2006). Bankruptcy evaluation of the Islamic banking industry (Jan and Marimuthu, 2015c). All the previous studies of the Islamic banking industry were concerned with the ongoing performance of Islamic banking industry. Instead of the great importance for accounting sustainability in the business strategies, the studies relating sustainability management of the Islamic banking industry are found scant in the literature (Aliyu et al., 2016). Overshadowing of Islamic banks sustainability management may lead towards some drastic economic, environmental and social challenges at the world level, especially in the Islamic banking countries where the share of Islamic banking is very significant.

Table 1. Domicile of Islamic banking industry across the world

\begin{tabular}{llllc}
\hline & Country & $\begin{array}{l}\text { Country Share in world } \\
\text { Islamic Banking }\end{array}$ & $\begin{array}{l}\text { Share of Islamic banking inside country } \\
\text { total banking assets }\end{array}$ & $\begin{array}{l}\text { Share in Billion } \\
\text { States dollar (USD) }\end{array}$ \\
\hline 01 & Saudi Arabia & 13.7 & 51.2 & 291 \\
02 & Malaysia & 9.8 & 21.3 & 137 \\
03 & U.A.E & 9.1 & 21.6 & 136 \\
04 & Kuwait & 9.0 & 45.2 & 89.0 \\
05 & Qatar & 04.1 & 25.8 & 72.0 \\
06 & Turkey & 02.7 & 05.5 & 45.0 \\
07 & Bahrain & 02.3 & 29.3 & 14.0 \\
08 & Indonesia & 01.5 & 03.7 & 22.0 \\
09 & Egypt & 01.3 & 04.0 & 8.60 \\
10 & Others & 46.5 & 00.0 & 385.4 \\
11 & Total & 100.0 & Avg 20.8 percent & 1.2 Billion $\left(10^{9}\right)$ \\
\hline
\end{tabular}

Source: (Young, 2011-2012, Young, 2013-2014). 
Table 1 first shows the share of an individual Islamic banking country in the total Islamic banking assets of the world. For instance, Saudi Arabia and Malaysia are the market leaders in the world Islamic banking assets with the share of $13.7 \%$ (Saudi Arabia) and $9.8 \%$ (Malaysia) respectively. Secondly, it shows the share of an Islamic banking country inside its total banking assets. Saudi Arabia (51.2\%), Kuwait (45.2\%), Qatar (25.8\%) have the highest Islamic banking share inside their country's total banking assets. In the third place, Table 1 shows the worth of an individual Islamic banking country's share in billion $\left(10^{9}\right)$ United States dollar (USD). It also illuminates the worth of an individual Islamic banking country assets size in USD. Saudi Arabia and Malaysia have the highest Islamic banking share worth of 291 and 137 billion $\left(10^{9}\right)$ USD. Islamic banking industry worldwide possesses the banking shares of approximately 1.2 trillion $\left(10^{12}\right)$ USD. To some scholars, the share is around 1.8 Trillion $\left(10^{12}\right)$ approximately (Mallin et al., 2014). The presence of such a high share demands high sustainability management. But literature suggests that the management of sustainability relating studies in the Islamic banking context are found scant (Meutia and Febrianti, 2017). Over-sighting, sustainability management may lead toward some serious economic, environmental and social challenges. Due to the central role of the banking industry, it accounts for the sustainable economic growth and development of the country (Hanif et al., 2012). Due to this dominance and the central role of the banking industry in the financial system, the threat of collapse to the economic system becomes ever more dependent on the working operations of the banking industry. Looking at the undeniable importance of the banking industry in the economic system, a collapse of the Islamic banking industry is almost unbearable. And therefore, the evaluation of economic sustainability for the Islamic banking industry becomes obligatory (Rashid and Nishat, 2009).

The banking industries while catering for the economic side of sustainability overshadow the negative impacts of its operations on society and the green environment (Saleem et al., 2013). Hence, due to the inefficient sustainability policies of such firms, the global world is not achieving its set milestones of social and the environmental sustainability (Sobhani et al., 2011). In the majority of the Muslim countries, the share of Islamic banking industry is very significant as shown in Table 1 . The large share of 1.2 trillion $\left(10^{12}\right)$ USD is fueling the massive transactions of the Islamic banking industry, and massive transaction level may ultimately contribute towards the massive unsustainable impacts of the Islamic banking activities on the society and the environment such as, carbon emissions from the banking activities, effluent and waste generations, ignoring funding's to the green energy projects, disturbing biodiversity through banking projects, producing product and services that are not friendly with the environmentally, violation of decent labor work practices, human rights violation in the society, not providing practical training and education to the society, product and service labeling are not in the compliance with the society, not accounting for anticorruption practices etc. This seems unethical because the banks are earning profit from the people and the environment, in return it must pay back to the society and the environment.

Looking at these detrimental effects of the banking activities on the society and environment it is highly recommended for the Islamic banking industry to adopt an efficient sustainability evaluation model to control the negative impacts of its activities on the environment and society. To comply with that, an efficient sustainability measurement model comprised of economic, environmental and social sustainability dimensions is needed. However, the literature suggests that the Islamic banking industry doesn't have its own Shariah compliant sustainability evaluation model, Islamic Reporting Initiatives (IRI). Secondly, the share of Islamic banking industry worldwide is on the rise, and the rising share may bring new economic, environmental and social challenges if not addressed promptly. This study focuses on Islamic banks in Malaysia only. The posited framework will evaluate the impact of sustainability practicing on the financial performance of the Islamic banking industry in Malaysia. Subsequently, the framework can be used as a benchmark by other Islamic banking countries. Islamic banking in Malaysia is chosen due to the prominence of Islamic banking and its importance to other Malaysian industries. For example, according to a master plan on the halal industry by the Ministry of International Trade and Industry (MITI) Malaysia, the percentage of gross domestic product (GDP) in Malaysian halal industry will reach to $8.7 \%$. The Global Halal economy is estimated at RM 8.4 trillion $\left(10^{12}\right)$ and Malaysia is the market leader in the Halal industry. These facts are further signifying the future dominant role of the Malaysian Islamic banking industry. Because the rational medium of exchange for controlling the huge Halal industry of Malaysia is the Islamic banking industry of Malaysia. Hence, these transformations urge the Islamic banks to take proactive steps towards its strong sustainability to handle the expected increase in the near future. Against this background, the objectives of the study are as follow.

\subsection{Objectives of the Study}

1. To propose a framework for measuring sustainability practices of the Islamic banking industry in Malaysia. 
2. To evaluate the theoretical impact of sustainability practices on financial performance of the Islamic banking industry in Malaysia.

3. To examine theoretically the moderating role of Shariah supervisory board size, and ownership structure between the relationship of sustainability practices and the financial performance of the Islamic banking industry Malaysia.

\section{Literature Review}

Literature suggests that there is not a unanimous and definite definition of Sustainability (Dusuki and Yusof, 2016). It is because the importance of any sustainability dimension i.e. Economic, Environmental, \& Social aspects differ from organization to organization. For example, the environmental sustainability may not be of that important for the banking industry, as compared to the manufacturing industries which emits the greenhouse gasses that are detrimental to the environment and vice versa. In the line of that, different organizations have perceived and defined sustainability from their unique perspective. The summary of sustainability definitions is presented in Table 2 below.

Table 2. History of Corporate Social Responsibility (CSR) / Corporate Sustainability (CS)

\begin{tabular}{|c|c|}
\hline $\begin{array}{l}\text { Author/ Year } \\
\text { Birth Era for CSR }\end{array}$ & Summary/ Definitions \\
\hline $\begin{array}{l}\text { Bowen (1953), } \\
\text { updated in Bowen } \\
(2013)\end{array}$ & $\begin{array}{l}\text { Bowen is formally known as the father of CSR he argued that the obligations of businesses are to make, assert and } \\
\text { follow those business policies which are beneficial for value creation in the society? }\end{array}$ \\
\hline Heald (1957) & $\begin{array}{l}\text { The CSR of business is beyond achieving the maximum economic performance only. But also to construct human } \\
\text { and social policies as well. }\end{array}$ \\
\hline Davis (1960) & $\begin{array}{l}\text { The study defined CSR as the set of business decisions which are partially taken beyond the direct economic or } \\
\text { technical business interests. }\end{array}$ \\
\hline Frederick (1960) & $\begin{array}{l}\text { The study drew attention to five different themes of CSR. Each one tackled the importance of business to the } \\
\text { society. }\end{array}$ \\
\hline $\begin{array}{l}\text { Walton }(1967) \text { as } \\
\text { cited by Rahman } \\
(2011)\end{array}$ & $\begin{array}{l}\text { The study developed the conceptual relationship between corporations and societies, it also stressed the top } \\
\text { managers to follow it. }\end{array}$ \\
\hline \multicolumn{2}{|c|}{ The Era of CSR Conceptualization } \\
\hline $\begin{array}{l}\text { Friedman (1970) } \\
\text { As cited by Nor and } \\
\text { Asutay (2011) }\end{array}$ & $\begin{array}{l}\text { Friedman took a line that the social responsibilities of business are to only earn more profit. The social welfare of } \\
\text { societies should to left for the government to decide. }\end{array}$ \\
\hline Johnson (1971) & Gave four new definitions about CSR as cited by (Rahman, 2011) \\
\hline Votaw (1972) & The study defined CSR as it is "something" but not always the same thing to everybody" \\
\hline $\begin{array}{l}\text { Soltow and Heald } \\
(1972)\end{array}$ & $\begin{array}{l}\text { The study conducted a detailed literature review and also defined the new social role of business manager in the } \\
\text { society. }\end{array}$ \\
\hline $\begin{array}{l}\text { Eilbirt and Parket } \\
(1973)\end{array}$ & $\begin{array}{l}\text { The study established the link of CSR with society by giving an example of "to think of it as good and the } \\
\text { neighborliness", }\end{array}$ \\
\hline Davis (1973) & $\begin{array}{l}\text { The responsibility of firms is to issue business obligations beyond the narrow technical, legal, and economics } \\
\text { requirements of the firm. }\end{array}$ \\
\hline $\begin{array}{l}\text { Preston and } \\
(1975)\end{array}$ & The study alluded that the role and scope of managerial activates are not unlimited in CSR. \\
\hline Sethi (1975) & Although CSR is an elusive concept, still it can be measured with an efficient structural framework. \\
\hline Fitch (1976) & $\begin{array}{l}\text { The intense response of the business is to solve the social problems caused due to the direct or indirect conduct of } \\
\text { business. }\end{array}$ \\
\hline Carroll (1979) & $\begin{array}{l}\text { Presented new model of CSR. The study also disapproved the idea that economic consideration is not necessary } \\
\text { during social responsibly. It also stressed that economic consideration should be the main part in CSR. }\end{array}$ \\
\hline Zenisek (1979) & Defined CSR as the fit between business ethics, and society's expectation of the business community. \\
\hline \multicolumn{2}{|c|}{ The CSR Implementation Era } \\
\hline $\begin{array}{l}\text { Jones (1980) } \\
\text { Tuzzolino } \\
\text { Armandi (1981) }\end{array}$ & $\begin{array}{l}\text { The organizations have responsibilities to different sectors of society beyond the stockholders. These are the } \\
\text { sectors which are suggested by different union contracts and by the law. } \\
\text { The study developed a new framework based on Maslow's theory for better operationalization and better } \\
\text { implementation of CSR. }\end{array}$ \\
\hline
\end{tabular}




\begin{tabular}{|c|c|}
\hline Strand (1983) & $\begin{array}{l}\text { he study outlined a new categorical model for implementing CSR in the organization. A clear distinction between } \\
\text { e descriptive, normative, and evaluative inquires about CSR were made in the model. }\end{array}$ \\
\hline Carroll (1983) & $\begin{array}{l}\text { The study divided the concept of CSR in four categories, namely the economic, ethical, legal, and philanthropic, as } \\
\text { cited by (Rahman, 2011). }\end{array}$ \\
\hline Edward (1984) & $\begin{array}{l}\text { Freeman who is known as the father of stakeholder theory presented the famous stakeholder theory about } \\
\text { successful CSR implementation. }\end{array}$ \\
\hline $\begin{array}{l}\text { Cochran and Wood } \\
\text { (1984) }\end{array}$ & The author presented a new methodology for identification of the relationship between CSR and firm performance. \\
\hline $\begin{array}{l}\text { Wartick and Cochran } \\
\text { (1985) }\end{array}$ & $\begin{array}{l}\text { Developed Corporate Social Performance (CSP) model by including economic responsibility, social } \\
\text { responsiveness, and public responsibility. }\end{array}$ \\
\hline Frederick (1986) & $\begin{array}{l}\text { The study divided CSR literature into three stages i.e. CSR1, CSR2, and CSR3. CSR1 represented the first wave of } \\
\text { CSR that started in the } 60 \text { 's. CSR2 represented the phase of moving from philosophical concepts towards } \\
\text { action-oriented management concepts. While CSR3 referred to as to the successful implementations of CSR } \\
\text { policies. }\end{array}$ \\
\hline Brundtland (1987) & $\begin{array}{l}\text { Pioneered the concept of corporate sustainability. It defined sustainability as "Development that meets the needs of } \\
\text { the present without compromising the ability of future generations to meet their own needs" }\end{array}$ \\
\hline Brown et al. (1987) & $\begin{array}{l}\text { The meaning of sustainability differs from organization to organization. Global sustainability could only be } \\
\text { achieved by setting global sustainability indicators. }\end{array}$ \\
\hline Butlin (1989) & $\begin{array}{l}\text { The report "Our Common Future" presented by the World Commission on Environment and Development defined } \\
\text { sustainability as "the ability to meet the current needs with compromising the needs for future generation". }\end{array}$ \\
\hline Epstein (1989) & $\begin{array}{l}\text { The societal obligations of the business outstrip is the economic activity of production and distribution of scarce } \\
\text { goods, and the profit generation activity. }\end{array}$ \\
\hline \multicolumn{2}{|c|}{ The Era of CSR Innovation } \\
\hline Carroll (1991) & $\begin{array}{l}\text { Presented a new framework for CSR known as a pyramid of CSR. The } \mathrm{p} \\
\text { business in four heads i.e. economic, legal, ethical, and philanthropic respol }\end{array}$ \\
\hline Pezzey (1992) & $\begin{array}{l}\text { The study proposed that sustainability models were required to incorporate both renewable and non-renewable } \\
\text { resources. }\end{array}$ \\
\hline Elkington (1994) & $\begin{array}{l}\text { The study coined the concept of Triple Bottom Line TBL approach to sustainability. TBL included environmental, } \\
\text { social, and economic dimensions. }\end{array}$ \\
\hline Suchman (1995) & $\begin{array}{l}\text { Suchman presented legitimacy theory in which he highlighted social and environmental disclosure of the firm in } \\
\text { line with its influence on the society. }\end{array}$ \\
\hline $\begin{array}{l}\text { Donaldson } \quad \text { and } \\
\text { Preston (1995) }\end{array}$ & $\begin{array}{l}\text { Donaldson presented the stakeholder's theory, through which he illuminated the ethical and moral business } \\
\text { practices by the management. This theory, later on, served as the base for the development of many sustainability } \\
\text { frameworks such as GRI framework etc. }\end{array}$ \\
\hline $\begin{array}{l}\text { Global } \quad \text { Reporting } \\
\text { Initiative (1997) as } \\
\text { cited by }\end{array}$ & $\begin{array}{l}\text { The pioneered study developed a framework composed of internationally recognized indicators for measuring } \\
\text { corporate sustainability. The framework is formally known as GRI framework. }\end{array}$ \\
\hline Brown et al. (2009) & \\
\hline Elkington (1997) & $\begin{array}{l}\text { Elkington presented the famous Triple Bottom Line (TBL) approach which included economic, environmental, and } \\
\text { social aspects of the business. It illustrated that socially responsible firms are the foundation for economic } \\
\text { prosperity, environment protection, and social equity. }\end{array}$ \\
\hline Frederick (1998) & Fredrick by proposing CSR4 urged the need of considering religion in CSR. \\
\hline Maclagan (1999) & The moral process through which individual's moral value and basic concern are addressed holistically. \\
\hline $\begin{array}{l}\text { Jeucken and Bouma } \\
(1999)\end{array}$ & $\begin{array}{l}\text { The study by looking up at the dynamic role of the banking industry helped in developing the environmental } \\
\text { sustainability framework for the banking industry. }\end{array}$ \\
\hline \multicolumn{2}{|c|}{ Modern Emergence of CSR } \\
\hline Moir (2001) & $\begin{array}{l}\text { Defined CSR from a } 21 \text { st-century perspective. And also illuminated that why the businesses must stick to this } \\
\text { concept. }\end{array}$ \\
\hline $\begin{array}{l}\text { McWilliams and } \\
\text { Siegel (2001) }\end{array}$ & $\begin{array}{l}\text { CSR is the notion of volunteer actions taken by firms that assist society beyond the interest of firm, and beyond } \\
\text { abiding by laws. }\end{array}$ \\
\hline Lantos (2001) & Divided CSR into three types i.e. strategic, ethical, and altruistic. \\
\hline $\begin{array}{l}\text { van der Wiele et al. } \\
(2001)\end{array}$ & $\begin{array}{l}\text { Defined CSR as the notion of volunteer funds used by the firm for the betterment of society, by participating as a } \\
\text { member of society. }\end{array}$ \\
\hline $\begin{array}{l}\text { De Bakker et al. } \\
(2005)\end{array}$ & $\begin{array}{l}\text { Reviewed } 30 \text { years of CSR literature regarding different views that were presented about CSR, and suggested } \\
\text { implications for future Research. }\end{array}$ \\
\hline Marrewijk & The study proposed that three aspects of sustainability i.e. economic, environmental, and social can be translated to \\
\hline
\end{tabular}




\begin{tabular}{ll}
\hline (2003) & the term corporate responsibility (De Bakker et al., 2005). \\
Jamali and Mirshak & The study highlighted the lack of CSR knowledge in the developing countries, and also highlighted its possible \\
negative implications to the society & The literature review study highlighted that there is still a confusion about a clear definition of CSR. The study \\
& further divided CSR into five dimensions including environmental, economics social, stakeholder and \\
voluntariness. & The study labelled the traditional CSR concept as CSR 1.0 and declared it to be a misnomer. The study proposed \\
CSR 2.0 and named it as "Corporate Sustainability and Responsibility.
\end{tabular}

Table 2 summarizes the history of sustainability/ Corporate Social Responsibility CSR literature in detail. The point of presenting evolution of sustainability here is to allude the fact that "how and when" the concept of corporate social responsibility gave birth to the modern concept of corporate sustainability. This study is with the view that, after the mid-80s which this study refers to as "The CSR Implementation era" holistically gave birth to the modern concept of corporate sustainability. It is because during the implementation phase the loopholes were identified and addressed accordingly. The concept kept on renewing until the Brundtland report appeared (Brundtland, 1987). The report introduced the modern concept of corporate sustainability for the first time. Furthermore, the subsequent era of 90's, which this study refers to as "The era of CSR Innovation" helped in the creation of modern-day sustainability frameworks. For instance, the sustainability framework developed by Global Research Initiatives (GRI) in 1997. The triple bottom line (TBL) approach by (Elkington, 1994, Elkington, 1997). Despite the abundance of CSR literature, there is not yet a concrete definition available. CSR has been defined in numerous ways such as corporate responsibility, corporate citizenship, sustainable development, Corporate Social Responsibility CSR, Triple Bottom Line TBL, but essentially they all serve a common purpose. In the modern day's studies, these concepts are used interchangeably by studies like (Carroll and Buchholtz, 2014). This study will be using the concept as Corporate Sustainability, which is consistent with the TBL approach presented by Elkington (1997), it involves the economic, social and environmental aspects of business sustainability.

Since its modern emergence, the topic of sustainability remains the area of pursuit to many researchers and organizations till date. The Asian financial crisis of 1997 and the subprime financial crisis of 2008 were the major events that gave new spirit to the topic of corporate sustainability. Despite so much importance for sustainability at the world level, the literature suggests that sustainability relating studies in the Islamic banks around the world are still found scant (Meutia and Febrianti, 2017). Consistent with it, the level of sustainability practicing and reporting from the Islamic banking industry in Malaysia is also found low (Jan and Marimuthu, 2016). Details about those studies are reported in Table 3 below.

Table 3. Corporate sustainability practicing from the Islamic banking industry

\begin{tabular}{|c|c|c|c|c|}
\hline Author/ Year & $\begin{array}{l}\text { Sample / } \\
\text { Time-Period }\end{array}$ & $\begin{array}{l}\text { Country } \\
\text { Region }\end{array}$ & $\begin{array}{l}\text { Reporting } \\
\text { Framework }\end{array}$ & Conclusion \\
\hline $\begin{array}{l}\text { Alsaadi et al. } \\
(2017)\end{array}$ & 2003-2013 & $\begin{array}{ll}10 & \mathrm{EU} \\
\text { countries } & \end{array}$ & Shariah index & $\begin{array}{l}\text { The study concluded that Shariah screening does not } \\
\text { fully comply with Islamic principles, and concentrate } \\
\text { less on CSR activities }\end{array}$ \\
\hline $\begin{array}{l}\text { Meutia and } \\
\text { Febrianti } \\
(2017)\end{array}$ & 14 Islamic banks & $\begin{array}{l}\text { Indonesia and } \\
\text { Malaysia }\end{array}$ & ISR index & $\begin{array}{l}\text { The study found that the level of sustainability } \\
\text { practices from the Islamic banks in Indonesia was } \\
\text { better than that of Islamic banks in Malaysia. }\end{array}$ \\
\hline $\begin{array}{l}\text { Nobanee and } \\
\text { Ellili }(2016)\end{array}$ & $\begin{array}{l}13 \text { listed banks from } \\
\text { the UAE financial } \\
\text { market for the years } \\
2003-2013\end{array}$ & UAE & $\begin{array}{l}\text { Sustainability } \\
\text { disclosure index }\end{array}$ & $\begin{array}{l}\text { The study found the overall sustainability practices of } \\
\text { selected Islamic banks at a low level. The sustainability } \\
\text { disclosures of conventional banks were found better } \\
\text { than that of Islamic banks. The study further concluded } \\
\text { that sustainability practicing positively affects the } \\
\text { performance of conventional banks and vice versa. }\end{array}$ \\
\hline $\begin{array}{l}\text { Belal et al. } \\
(2015)\end{array}$ & $\begin{array}{l}\text { Islami } r \text { Bank } \\
\text { Bangladesh limited } \\
\text { IBBL, for the period } \\
\text { 1983-2010 }\end{array}$ & Bangladesh & Interviews & $\begin{array}{l}\text { The study found that the selected Islamic bank failed in } \\
\text { providing full level disclosure. }\end{array}$ \\
\hline $\begin{array}{l}\text { Jan and } \\
\text { Marimuthu } \\
(2015 b)\end{array}$ & $\begin{array}{l}\text { Top } 5 \text { Islamic IB } \\
\text { countries based on } \\
\text { their total assets from } \\
(2009-2013)\end{array}$ & Malaysia & $\begin{array}{l}\text { Altman's (2000) } \\
\text { model }\end{array}$ & $\begin{array}{l}\text { Saudi Arabian IBs were found highly sustainable. } \\
\text { While Malaysian IBs were found not-sustainable. The } \\
\text { overall sampled Islamic banks were found less } \\
\text { sustainable. }\end{array}$ \\
\hline and & Top 5 Islamic banking & Malaysia & Conceptual & Bankruptcy can be used as a proxy for measuring \\
\hline
\end{tabular}




\begin{tabular}{|c|c|c|c|c|}
\hline $\begin{array}{l}\text { Marimuthu } \\
\text { (2015a) }\end{array}$ & $\begin{array}{l}\text { countries based on } \\
\text { their total assets }\end{array}$ & & framework & economic sustainability \\
\hline $\begin{array}{l}\text { Mallin et al. } \\
(2014)\end{array}$ & $\begin{array}{l}90 \text { Islamic banks for } \\
\text { the years } 2010-2011\end{array}$ & $\begin{array}{l}12 \text { Muslim } \\
\text { countries, } \\
\text { along with the } \\
\text { UK }\end{array}$ & CSR index & $\begin{array}{l}\text { The study found that less attention was paid by the } \\
\text { Islamic banks towards the voluntary disclosures, } \\
\text { especially to the environmental dimension. } \\
\text { Furthermore, the study found a positive relationship } \\
\text { between sustainability practices and financial } \\
\text { performance of the Islamic banks. }\end{array}$ \\
\hline $\begin{array}{l}\text { Nor and } \\
\text { Hashim (2014) }\end{array}$ & $\begin{array}{l}\text { Interviews were taken } \\
\text { from } 11 \text { important IB } \\
\text { officers at Kuala } \\
\text { Lumpur. }\end{array}$ & Malaysia & $\begin{array}{l}\text { Face to face } \\
\text { interview }\end{array}$ & $\begin{array}{l}\text { Little is known about the sustainability practices of } \\
\text { Malaysian IBs from a managerial point of view. }\end{array}$ \\
\hline $\begin{array}{l}\text { Yusoff and } \\
\text { Darus (2014) }\end{array}$ & $\begin{array}{l}37 \text { Islamic financial } \\
\text { institutions including } \\
17 \text { Islamic banks for } \\
\text { the year } 2012\end{array}$ & Malaysia & $\begin{array}{l}\text { CSR } \\
\text { environmental } \\
\text { index }\end{array}$ & $\begin{array}{l}\text { The study found that the overall environmental } \\
\text { sustainability practices by the Malaysian financial } \\
\text { institutions were very low. }\end{array}$ \\
\hline $\begin{array}{lr}\text { Ahmed } & \text { Haji } \\
\text { and } & \text { Anum } \\
\text { Mohd } & \text { Ghazali } \\
(2013) & \end{array}$ & $\begin{array}{l}76 \text { Shariah-compliant } \\
\text { companies for the year } \\
2009\end{array}$ & Malaysia & $\begin{array}{l}\text { Corporate } \\
\text { voluntary } \\
\text { disclosure index }\end{array}$ & $\begin{array}{l}\text { The study found that the quality of voluntary disclosure } \\
\text { from the Shariah compliant companies in Malaysia was } \\
\text { very low. }\end{array}$ \\
\hline $\begin{array}{l}\text { Amalina Wan } \\
\text { Abdullah et al. } \\
(2013)\end{array}$ & $\begin{array}{l}\text { A total of } 23 \text { Islamic } \\
\text { banks from both the } \\
\text { countries. Only one } \\
\text { year data of } 2009 \text { were } \\
\text { used }\end{array}$ & Malaysia & $\begin{array}{l}\text { Built Shariah } \\
\text { Supervisory } \\
\text { Board index } \\
\text { (SSB index) }\end{array}$ & $\begin{array}{l}\text { Disclosure about Shariah supervisory board and Zakat } \\
\text { were found limited in the annual reports. }\end{array}$ \\
\hline Hamza (2013) & $\begin{array}{l}\text { The Shariah } \\
\text { governance } \\
\text { framework of } \\
\text { Malaysia and Gulf } \\
\text { Cooperation Council }\end{array}$ & Malaysia & $\begin{array}{l}\text { Centralized and } \\
\text { decentralized } \\
\text { Shariah } \\
\text { framework }\end{array}$ & $\begin{array}{l}\text { Centralized Shariah framework as in Malaysia is } \\
\text { proved beneficial to its IB industry }\end{array}$ \\
\hline $\begin{array}{l}\text { Farook et al. } \\
(2011)\end{array}$ & $\begin{array}{l}47 \text { Islamic banks } \\
\text { during the year } 2000\end{array}$ & 14 countries & CSR disclosure & $\begin{array}{l}\text { The social disclosures of selected Islamic banks were } \\
\text { found very low. }\end{array}$ \\
\hline $\begin{array}{l}\text { Aribi and Gao } \\
(2011)\end{array}$ & $\begin{array}{l}21 \text { Islamic financial } \\
\text { institution }\end{array}$ & Gulf region & Content analysis & $\begin{array}{l}\text { The study found that the highest corporate social } \\
\text { responsibility disclosure was relating to Shariah } \\
\text { supervisory board size. }\end{array}$ \\
\hline $\begin{array}{l}\text { Nor and Asutay } \\
(2011)\end{array}$ & $\begin{array}{l}477 \text { Questionnaires } \\
\text { send to the customers } \\
\text { of Klang and Kuala } \\
\text { Lumpur }\end{array}$ & Malaysia & $\begin{array}{l}\text { Survey } \\
\text { questionnaire. }\end{array}$ & $\begin{array}{l}\text { Opinion related to "sustainability practices" and } \\
\text { "economic development" was found discouraging }\end{array}$ \\
\hline $\begin{array}{l}\text { Rahman et al. } \\
(2010)\end{array}$ & $\begin{array}{l}\text { Data from } \\
(1992-2005) \text { for the } \\
\text { Bank Islam Malaysia } \\
\text { Berhad (BIMB) }\end{array}$ & Malaysia & $\begin{array}{l}\text { Adapted Maali et } \\
\text { al. } \quad(2006) \\
\text { framework }\end{array}$ & $\begin{array}{l}\text { Sustainability practices of the Bank Islam Malaysia } \\
\text { Berhad was found with upward trend during } \\
(1992-2005)\end{array}$ \\
\hline $\begin{array}{l}\text { Hassan and } \\
\text { Syafri Harahap } \\
(2010)\end{array}$ & $\begin{array}{l}7 \text { Islamic banks for the } \\
\text { year } 2006\end{array}$ & $\begin{array}{l}\text { Bahrain, } \\
\text { Bangladesh, } \\
\text { Indonesia, } \\
\text { Malaysia, } \\
\text { KSA, UAE, } \\
\text { Kuwait }\end{array}$ & CSR index & $\begin{array}{l}\text { The study found that the sustainability disclosures was } \\
\text { not of major concern to the Islamic banks. }\end{array}$ \\
\hline $\begin{array}{l}\text { Haniffa and } \\
\text { Hudaib (2007) }\end{array}$ & $\begin{array}{l}7 \text { Islamic banks for the } \\
\text { year 2002-2004 }\end{array}$ & $\begin{array}{l}\text { Bahrain, } \\
\text { Qatar, Oman, } \\
\text { KSA, UAE, } \\
\text { Kuwait }\end{array}$ & $\begin{array}{l}\text { Ethical identity } \\
\text { index }\end{array}$ & $\begin{array}{l}\text { The study concluded that the Islamic banks suffered } \\
\text { from a disparity between communicated and the ideal } \\
\text { ethical identities. }\end{array}$ \\
\hline Dusuki (2005) & $\begin{array}{l}1780 \text { questionnaires } \\
\text { were sent to the } \\
\text { various stakeholders } \\
\text { of IBs in Malaysia }\end{array}$ & Malaysia & $\begin{array}{l}\text { Questionnaire } \\
\text { containing } 24 \\
\text { questions } \\
\text { used }\end{array}$ & $\begin{array}{l}\text { customers were found satisfied with the sustainability } \\
\text { practices of the Islamic banks in Malaysia }\end{array}$ \\
\hline
\end{tabular}

Table 3 shows the low level of sustainability practicing and reporting from the Islamic banking industries around the world and specifically in Malaysia. It shows that sustainability practicing and reporting from Islamic banking industry around the world as well as in Malaysia is very low. This low sustainability practicing may affect the financial performance of the Islamic banks. It is because evidence shows that sustainability practices increases financial performance of the Islamic banks (Platonova et al., 2016). Table 3 illuminates that a comprehensive sustainability study related to Islamic banks in Malaysia is missing. This study opted to fill the gap by developing a sustainability measurement framework for the Islamic banks in Malaysia. The proposed 
model will be tested against the financial performance of the Islamic banks in Malaysia. In the subsequent section this study explains the financial performance of the Islamic banks and the different ratios used for measuring it in the Islamic banking industry.

\section{Sustainability Practicing and Reporting from the Islamic Banking Industry in Malaysia}

The Islamic banking industry is growing faster than conventional banking industry in Malaysia (Hachicha and Amar, 2015). The asset size of Islamic and conventional banks in Malaysia will become equal by the year 2025 . The increase in the Islamic banking share has a significant relationship with the GDP growth rate of Malaysia. With such a high future dominance of the Islamic banking industry in Malaysia, its strong sustainability is highly required. Otherwise, it would lead towards some economic, environmental, and social calamities as discussed below

\subsection{Economic Sustainability of Malaysian Islamic Banks}

Table 4. Domicile of Malaysian Islamic Banking Industry

\begin{tabular}{lll}
\hline Particular & Share in the Global Market & Share in the Domestic Market \\
\hline Islamic Banking Industry of Malaysia & $15.05 \%$ & $21.03 \%$ \\
\hline
\end{tabular}

Source: (Young, 2016).

In Table 4 the percentage figures are based on total assets. First, it shows the share of Malaysian Islamic banking industry inside the world Islamic banking industry. Secondly, it shows the share of Malaysian Islamic banking industry inside its country's total banking assets. These significant shares urge Malaysian Islamic banks to maintain high economic sustainability both domestically and internationally. Domestically the economic sustainability of Malaysian Islamic banks is vital for the accomplishment of its country's current development plan of 2016-2020, and also for the post-2020 developmental plans. Because evidence shows that, in Malaysia, the Islamic banking share got a significant positive relationship with the country's GDP growth rate (Hachicha and Amar, 2015) . From an international perspective, as Malaysia is the second largest Islamic banking country by assets size, it is vital for the market leaders of the Islamic banks to display strong economic sustainability for avoiding any economic disturbance at the world level. Singh (2016), argued that incorporating sustainability policies increases the adaptability chances for the banks to progress at the international level. Therefore, it is essential for the Malaysian Islamic banking industry to integrate effective economic sustainability policies in line with the Shariah principles to attract more customers internationally. In case of economic failure by the Malaysian Islamic banking industry, it will sow its seeds of economic destruction inside Malaysia and also outside Malaysia where its share is significant. However, to achieve high economic sustainability the key for Malaysian Islamic banking industry lies in a close tie with the Shariah principles. Because, it will hold the faith of customers in their operations, and subsequently, its Islamic banking industry will progress.

\subsection{Environmental Sustainability of Malaysian Islamic Banks}

Table 5. Top four countries in Asia with negative climate change ratios

\begin{tabular}{lllll}
\hline & Countries & Climate Index (2016) & Climate Index (2017) & Two Years Average \\
\hline $\mathbf{0 1}$ & Malaysia & -71.17 & -79.43 & -75.3 \\
$\mathbf{0 2}$ & Singapore & -66.63 & -71.47 & -69.05 \\
$\mathbf{0 3}$ & Philippine & -26.98 & -44.10 & -35.54 \\
$\mathbf{0 4}$ & Thailand & -23.25 & -20.21 & -21.72 \\
\hline
\end{tabular}

Source: (NUMBEO, 2017).

Table 5 shows the top four Asian countries with negative climate change ratios. Malaysia got the highest negative climate index ratio in entire Asia. More importantly, a negative upward trend is recorded from -71.17 in 2016 to -79.43 in 2017. A study illuminating the correlation of climate change with global health issues explained that 800,000 deaths occur annually from urban air pollution, while $1.5 \times 10^{6}$ million deaths from the indoor air pollution take place (Campbell-Lendrum and Corvalán, 2007). Zainal and Zainuddin (2013), argued 
that the rapid industrial growth in Malaysia can further contribute to its negative climate change ratio, and environmental degradation of the country if the business activities are not monitored properly. The role of the banking industry is considered to be relatively environmentally friendly regarding pollution and emission. The behaviour of banking industry in evaluating the environmental performance of their clients is found very slow and inefficient (Jeucken and Bouma, 1999). The Malaysian Islamic banks must account for their banking activities impact on the environment, so that it does not contribute to the negative climate change ratio of Malaysia. For the purpose, the Islamic banks in Malaysia need to develop a framework for monitoring the environmental performance of their clients and suppliers. Furthermore, the Islamic banks in Malaysia need to comply with the concept of "environmental investment funds. In the process, the Islamic banks need to grant quota funds on a priority basis to those organizations which are involved in the renewable energy projects, material and water recycling projects and are engaged in protecting biodiversity etc. In addition, the Islamic banks in Malaysia also need to initiate awareness programs relating to the reduction in the energy consumption and must comply with the standards of producing eco-friendly products and services. Therefore, an efficient framework is required which incorporates all these items needs to be developed. And the banks must start reporting and practicing about these measures in their annual reports.

\subsection{Social Sustainability of Malaysian Islamic Banks}

Research on the social sustainability concerns of the banks has been found limited (Colantonio, 2007, Lehtonen, 2004). The social sustainability of Malaysian Islamic banks is necessary to upholding the decent labour work practices, to promote human rights in the society, to provide Islamic training and education to their employees, to promote anti-corruption practices, and to provide funding for philanthropic work in the society (Hassan and Syafri Harahap, 2010). It is likely that in the final sprint by Malaysian corporation including its Islamic banks while in the quest of becoming a fully developed country by 2020 may shift their focus more toward the economic side, and in the process, the social sustainability standards can be possibly ignored. As already some corporate social misconduct issues recorded in some Malaysian firms, i.e., Malaysia Transmile Group Berhad, Megan Media Holdings Berhad (Zainal and Zainuddin, 2013). Hence, an efficient corporate sustainability measurement framework is required to measure the role of Malaysian Islamic banks in the society. Against these economic, environmental and social challenges faced by the Islamic banks in Malaysia, the research questions and objectives of the study are discussed below.

\subsection{Banks Financial Performance}

Measuring company performance is significant as it provides information on organizational objectives and how well they have been achieved. It assists firms to attract investors, as investors monitor a firm's overall performance in making investment decisions, whether to initiate, to stay or to quit an investment. It is often noted that in the management discipline, measuring a firm's performance is widely addressed subject and the ultimate dependent variable of interest. Firm performance can be measured using various metrics (Richard et al., 2009). The organization gains an advantage if they choose the best approach for measuring their performance. Two methods i.e. "perceived" and "objective: measures are being used in the literature for measuring firm's performance. Perceived measures are also known as subjective measures, where primary data collected through survey and questionnaire instruments are used to measure firm performance (Selvarajan et al., 2007). Objective measures are normally secondary data such as financial data. According to Richard et al. (2009) objective measures are classified into accounting, market and hybrid measures by means of which organizations can measure their performance. Objective measures are further categorized into two i.e. financial performance, market performance. Different ratios have been used to measure financial and market performance of the Islamic banks. Summary of the studies which used different ratio for measuring banks financial performance in the Islamic banks are presented in Table 6 below.

Table 6. Ratios used for measuring financial performance in the Islamic banking industry

\begin{tabular}{lll}
\hline Author & Ratio & Definition and Operationalization \\
\hline Platonova et al. (2016) & ROAE & Return on average equity: (net income / average total equity) \\
& ROAA & Return on average assets: (net income / average total assets) \\
Mollah and Zaman (2015) & ROAE & Return on average equity: (net income / average total equity) \\
& ROAA & Return on average assets: (net income / average total assets) \\
& Tobin's Q & Market value of equity + book value of liabilities / book value of assets \\
Naushad and Malik (2015) & Tobin's Q & Total market value of firm / Total assets \\
& ROTA & Return on total assets: (operating income / total assets) \\
\hline
\end{tabular}




\begin{tabular}{|c|c|c|}
\hline Abduh and Idrees (2013) & ROA & Net income / total assets \\
\hline $\begin{array}{l}\text { Wasiuzzaman and Nair } \\
\text { Gunasegavan (2013) }\end{array}$ & ROAA & Income after tax / total assets \\
\hline \multirow[t]{3}{*}{ Hanif et al. (2011) } & COSR & Cost income ratio \\
\hline & ROA & Net profit / total assets \\
\hline & ROE & Net profit / total assets \\
\hline \multirow[t]{2}{*}{ Akhtar et al. (2011) } & ROE & Earnings Available for common stockholders / Common Stock Equity \\
\hline & ROA & Net income / total assets \\
\hline \multirow[t]{3}{*}{ Bashir (1999) } & ROA & Net income / total assets \\
\hline & ROE & Net income / total equity \\
\hline & ROD & Net income / total investment deposits \\
\hline
\end{tabular}

Table 6 shows ratios which were used to measure financial performance in the Islamic banking industry. It also shows the different measurement techniques used for measuring these ratios. The subsequent section shows the link of sustainability practices with firm performance in the Islamic banking context.

\subsubsection{Sustainability Practices and Banks Financial Performance: The Stakeholder's Theory Perspective}

Freeman presented the stakeholder's theory in 1984, which attempts to address the "principle of who or what really counts (Freeman, 1984). While proposing the theory, Freeman divided the stakeholders into two main categories, i.e., direct and indirect stakeholders. Different researchers have reported them with different names. For instance, Clarkson (1995), referred them to as the primary and secondary stakeholders. Lépineux (2005), mentioned them to as the business and social stakeholders. The stakeholders 'theory argues that the value of firm increases when the multiple stakeholders, i.e., internal \& external are addressed and satisfied. The satisfaction of internal and external stakeholders can be attained through efficient sustainability reporting and practices. Economic sustainability practices addresses the internal stakeholders explicitly. While the environmental and social sustainability practices are involved in addressing the external stakeholders, that are people and planet. Some past studies are also consistent with the view that sustainability practices improves the value of the firm (Ameer and Othman, 2012). In the Islamic banking perspective, studies have also found a positive relationship between sustainability practices and banks financial performance (Mallin et al., 2014). Against this background, and in line with the stakeholder's theory this study argues that sustainability practising will increase the financial performance of the Islamic banks in Malaysia.

3.4.2 Moderating role of Shariah Supervisory Board Size and Director's Ownership: The Resource-Based View Theory Perspective

Wernerfelt (1984), presented the Resource-Based View (RBV) theory, which argue that the basis for the competitive advantage of a firm lies primarily in the application of a bundle of valuable tangible and intangible resources at the firm's disposal. In short, the RBV alludes that, improving and accelerating the internal activities of the firm can help the company to get an external competitive advantage, which ultimately increases the value of the firm. The RBV theory has already been used as a moderating variable between sustainability practicing and firm's financial performance. This study is using RBV theory in the Islamic banking context with the unique moderating variables of Shariah governance and director's ownership between the corporate sustainability practices and the value of the firm. It is because due to the big Shariah supervisory board size the capacity of monitoring increases, which facilitate better decision making (Hashim et al., 2015). And the better decision making leads towards, the better corporate sustainability practicing. Ultimately, the better corporate sustainability practices improves the value of the firm (Ameer and Othman, 2012). As per the second moderating variable, the director's ownership means those board of directors which possess shares of the company as well. These directors are highly motivated towards the better decisions made by the board because they are the ones who will directly get affected by the decision made by their board because they have the share of the company as well. It is highly expected that higher is the director's ownership in the firm, higher will be the firm's financial performance (Mishra and Suar, 2010)

\subsection{Controlled Variables}

Two controlled variables namely bank size and banks age are used in this study. The assets size of a bank normally depends upon its age. Hence both are complementary to each other. Bank size is one of the frequently used controlled variables in explaining the relationship between sustainability practicing and the banks performance. It is because, the large banks receive more attention from the public, media, and the policymakers. 
And the banks which are politically visible often get more criticized by the interest groups that are advocating about the green environmental policies and improved social welfare. As a result, these large banks disclose more information about being environmentally friendly and socially responsible for pacifying these pressure groups (Naser et al., 2006). As a result of these higher disclosures, the financial value of the banks increases, which implies that bank age and bank size does change the financial value of banks by sustainability practices and hence these variables needs to be controlled.

\subsection{Conceptual Framework of the Study}

In the line of theoretical and literature support, this study posits the conceptual framework as reported in Figure 1 below. The causality between sustainability practices and banks financial performance is being used bidirectionally in the literature. Waddock and Graves (1997), determined sustainability practices as a dependent while firm's financial performance as an independent variable. Their study alluded that firms with better performance have slack resources available to spend on sustainability practices and activities. Contrary to it, Waddock and Graves (1997), the social impact hypothesis of Cornell and Shapiro (1987), and the trade-off hypothesis determines firm's financial performance as the dependent while sustainability practices as the independent variable. In case of Islamic banking industry researchers have used banks financial performance as the dependent while sustainability practices as the independent variable (Platonova et al., 2016). Against that background, this study uses banks financial performance as the dependent while sustainability practices as the independent variable. As shown in Figure 1, business sustainability has main three dimensions i.e. economic, environmental and social sustainability, blended with integrated sustainability strategies. This study measures banks financial performance from three different perspective i.e., management perspective, market perspective, and the shareholders' perspective. Different researchers have proposed different ratios for measuring management, market and shareholder's perspective in the Islamic banking industry. Mollah and Zaman (2015), used Return on Average Assets (ROAA), Return on Assets (ROA) for measuring firm performance of the Islamic banks from management perspective. Naushad and Malik (2015), used Tobin's Q ratio for measuring firm performance of Islamic banks from market perspective. Hanif et al. (2011), used Return on Equity (ROE), and Return on Average Equity (ROAE) ratios for measuring financial performance of Islamic banks from shareholder's perspective

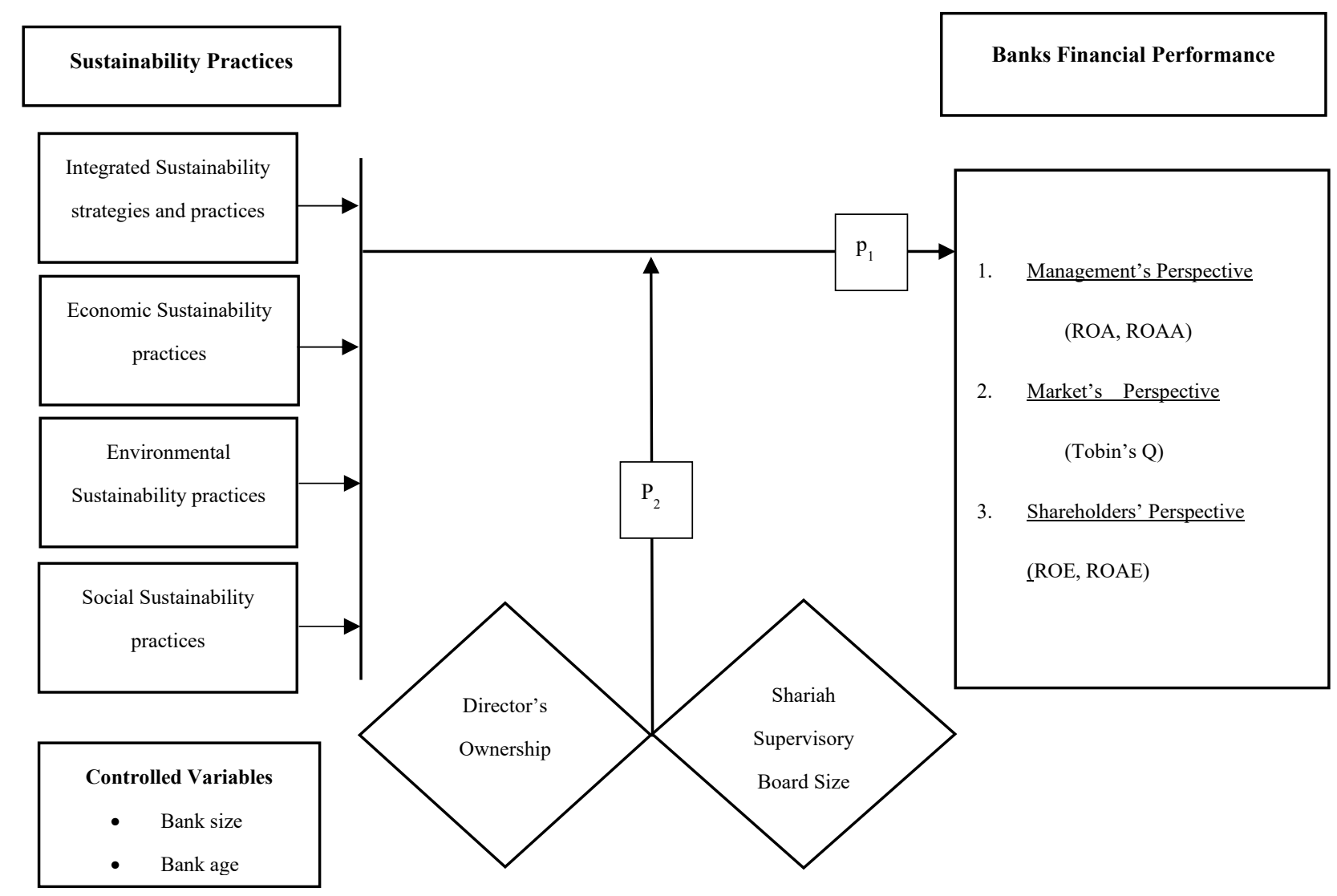

Figure 1. Conceptual framework of the study 


\subsection{Development of Propositions}

According to Mallin et al. (2014), the findings of the majority of studies like that of Preston and O'bannon (1997), Waddock and Graves (1997), which drawn a natural or negative relationship between sustainability practices and firm's financial performance are controversial. Because they only offered conceptual interpretation of it. The trade-off hypothesis also assumes a negative relationship between sustainability practices and firm's financial performance. On the other hand, some empirical studies found the relationship between sustainability practicing and firm's financial performance to be positive. Ameer and Othman (2012), in context of the banking industry, pointed that the link between banks social and financial performance is positive. In the Islamic banking context, Platonova et al. (2016), indicated that sustainability practices of the Islamic banks in Gulf Cooperation Council GCC region has a significant positive impact on its financial performance. The study of Mallin et al. (2014), also highlighted a positive association between sustainability practicing and the financial performance of the Islamic banks. The stakeholder's theory presented by Freeman (1984), also postulates a positive relationship between sustainability practices and better firm performance. Against this background, the propositions of the study are as fallow.

Proposition 1: Sustainability practices has a significant positive impact on the financial performance of the Islamic banking industry in Malaysia

In past studies have found a positive relationship of Shariah supervisory board with high sustainability practicing. Hashim et al. (2015), found that Shariah supervisory board size is positively related to sustainability practices. Mallin et al. (2014), found a positive association between the Shariah supervisory board size and sustainability practices of the Islamic banks across 13 countries.

Haniffa and Cooke (2005), found a significant relationship between corporate social discloser and ownership structure. Farook et al. (2011), argued that there is a positive association between ownership structure and the level of sustainability practices reported by the Islamic banks in their annual reports. Hashim et al. (2015), found a significant relationship between corporate social discloser and foreign share ownership. Kiliç (2016), found that ownership diffusion has a significant positive impact on the level of sustainability practicing of the Turkish banking industry. Against this background, the following proposition is proposed.

Proposition 2: Shariah supervisory board size and Director's ownership have a positive significant moderating effect on the relationship between sustainability practicing and the financial performance of the Islamic bank in Malaysia.

\section{Methodology}

\subsection{Development of a Corporate Sustainability Measurement Framework}

In line with the first objective that is "to propose a framework for measuring sustainability practices of the Islamic banking industry in Malaysia" this study adopted the following steps. In Islamic context, the framework used for measuring corporate sustainability practices is missing (Dusuki and Abdullah, 2007). Empirical evidence also shows that little is known about corporate sustainability disclosures in the annual reports of the Islamic banks. Hassan and Syafri Harahap (2010), found that sustainability disclosures were not of major concerns for the Islamic banks, and the sustainability disclosures in the annual reports of the Islamic banks were found scant. Table 7 shows the corporate sustainability disclosure items used for measuring corporate sustainability in the Islamic context.

Table 7. Corporate sustainability disclosures used in the Islamic context

\begin{tabular}{lll}
\hline \multirow{2}{*}{ Author \&Year } & $\begin{array}{l}\text { No } \\
\text { Items }\end{array}$ & of \\
& & Themes \\
\hline & Strategy \\
& Governance (Shariah compliant) \\
& Shariah screening during the investment \\
& Allocation of profit based on Shariah principles \\
Amran et al. (2017) & Nature of unlawful transactions \\
& Product \\
& Community Development and Social Goals \\
& Employment \\
& Environment \\
& \\
\end{tabular}




\begin{tabular}{|c|c|c|}
\hline \multirow{6}{*}{ Platonova et al. (2016) } & \multirow{6}{*}{56} & Mission and vision statement \\
\hline & & Products and services \\
\hline & & Zakat, charity and benevolent funds \\
\hline & & Commitment towards employees \\
\hline & & Commitment towards debtors \\
\hline & & Commitment towards community \\
\hline \multirow{7}{*}{ Aribi and Gao (2011) } & \multirow{7}{*}{58} & Employee \\
\hline & & Community \\
\hline & & Charity and Zakat \\
\hline & & Customer \\
\hline & & Product and service \\
\hline & & Shariah Supervisory Board Report SSBR \\
\hline & & Islamic values \\
\hline \multirow{8}{*}{$\begin{array}{l}\text { Hassan and Syafri Harahap } \\
(2010)\end{array}$} & \multirow{8}{*}{38} & Ethical behavior, stakeholder engagement, and customer relations \\
\hline & & Good governance \\
\hline & & Interest-free, lawful products, and services \\
\hline & & Shariah Supervisory Board (SSB) \\
\hline & & Development and social goal \\
\hline & & Employees \\
\hline & & Environment \\
\hline & & Research and development. \\
\hline \multirow{6}{*}{ Othman and Thani (2010) } & \multirow{6}{*}{43} & Employees \\
\hline & & Society \\
\hline & & Environment \\
\hline & & Corporate Governance \\
\hline & & Finance and Investment \\
\hline & & Product \\
\hline \multirow{9}{*}{ (Haniffa and Hudaib, 2007) } & \multirow{9}{*}{78} & Vision and mission statement \\
\hline & & BOD and top management \\
\hline & & Product \\
\hline & & Developmental and social goals \\
\hline & & Zakat, charity and benevolent loans \\
\hline & & Employees \\
\hline & & Debtor \\
\hline & & Community \\
\hline & & Shariah Supervisory Board SSB \\
\hline \multirow{9}{*}{ Maali et al. (2006) } & \multirow{9}{*}{28} & $\begin{array}{l}\text { Sharia opinion Report of Sharia Supervisory Board Required Unlawful (haram) } \\
\text { transaction }\end{array}$ \\
\hline & & Zakat (for banks required to pay it) \\
\hline & & Zakat (for banks not required to pay it) \\
\hline & & Qardh-e- Hassan \\
\hline & & Charitable and social activities \\
\hline & & Employees \\
\hline & & Late repayments and insolvent clients \\
\hline & & Environment \\
\hline & & Other aspects of community involvement \\
\hline \multirow{10}{*}{ Dusuki (2005) } & \multirow{10}{*}{16} & Fostering Islamic values upon staffs \\
\hline & & Solving social problems \\
\hline & & Listening to public view and concern \\
\hline & & Granting interest-free loan (Qardh Hasan) \\
\hline & & Workers health and safety \\
\hline & & Energy and water conservation \\
\hline & & Waste recycling policies \\
\hline & & Financing companies not harming environment \\
\hline & & Financing companies not violating human right \\
\hline & & Financing SMEs \\
\hline
\end{tabular}




\begin{tabular}{ll}
\hline & Providing affordable service to deprived areas \\
& Supporting charities and community projects \\
& Workers education and training \\
& Fair treatment to workers and applicants \\
& Paying zakat and giving Sadaqah consistently \\
& Mission statement and corporate objectives \\
& Top management \\
& Employees \\
& Community \\
Haniffa et al. (2004) & Islamic value \\
Shariah Supervisory Board & Audit process \\
Products \\
\hline
\end{tabular}

Table 7 shows the past studies that used different items to measure sustainability practices in the Islamic context. Majority of the past studies have used broader themes to measure sustainability practices. None of the studies placed those items into the three dimensions of sustainability i.e. economic, social, and environmental sustainability as confined by Global Reporting Initiatives GRI and Elkington (1997).

Against that background, in light of the theory "Maqasid Al-Shariah' this study opted to propose a sustainability measurment framework by transforming the GRI framework". The reasons of choosing GRI framework are its high popularity and its uniqueness of categorizing sustainability items into three dimensions of economic, environmental, and social sustainability. Sobhani et al. (2011), adopted GRI themes for developing a robust instrument for measuring sustainability practices of the banking industry in Bangladesh. Khan et al. (2011), evaluated sustainability practices and reporting of Bangladeshi banks based on GRI framework. The existing GRI framework published by the United Nations Environment Program UNEP is the most comprehensive framework for measuring corporate sustainability. However, it is not entirely compatible and sufficient for measuring sustainability practices and reporting of the Islamic banking industry. Because the existing GRI framework is not based on the Islamic principles. Measuring sustainability practices and reporting of the Islamic banks would be more appropriate by making required structural changes to the subjected framework in line with the Shariah principles. For making required changes to the model this study adapted sustainability measurement items that were used in the Islamic context (see Table 7). The Islamic items shortlisted from Table 2 were then accordingly incorporated to the GRI framework with the support of Maqasid Al-Shariah theory presented by Al-Ghazali as reported by

(Yusof et al., 2015). According to the theory, Shariah rulings aim is to preserve public interest (Maslahah) in all aspects of life. The theory has already been used in the Islamic finance studies. Rusydiana and Al Parisi (2016), used Maqasid Al-Shariah theory to measure profitability of the Islamic banks in Indonesia. Asutay and Harningtyas (2015), developed an index based on the theory of Maqasid Al-Shariah for measuring social sustainability practices of the Islamic banks. Colantonio (2007), used the theory for measuring the financial performance of Indonesian and Jordanian Islamic banks. Abdul Razak et al. (2008), used Maqasid Al-Shariah theory for measuring the financial performance of Islamic banks from six countries. Chapra et al. (2008), illuminated the Islamic vision of financial development in light of the theory of Maqasid Al-Shariah. Hameed et al. (2004), used the theory to identify social and environmental performance disclosure measure for the Islamic banks. Consistent with past literature, this study is also using the theory of Maqasid Al-Shariah for testifying any sustainability items as an Islamic item, and subsequently incorporating it into the economic, environmental, and social sustainability dimension. 


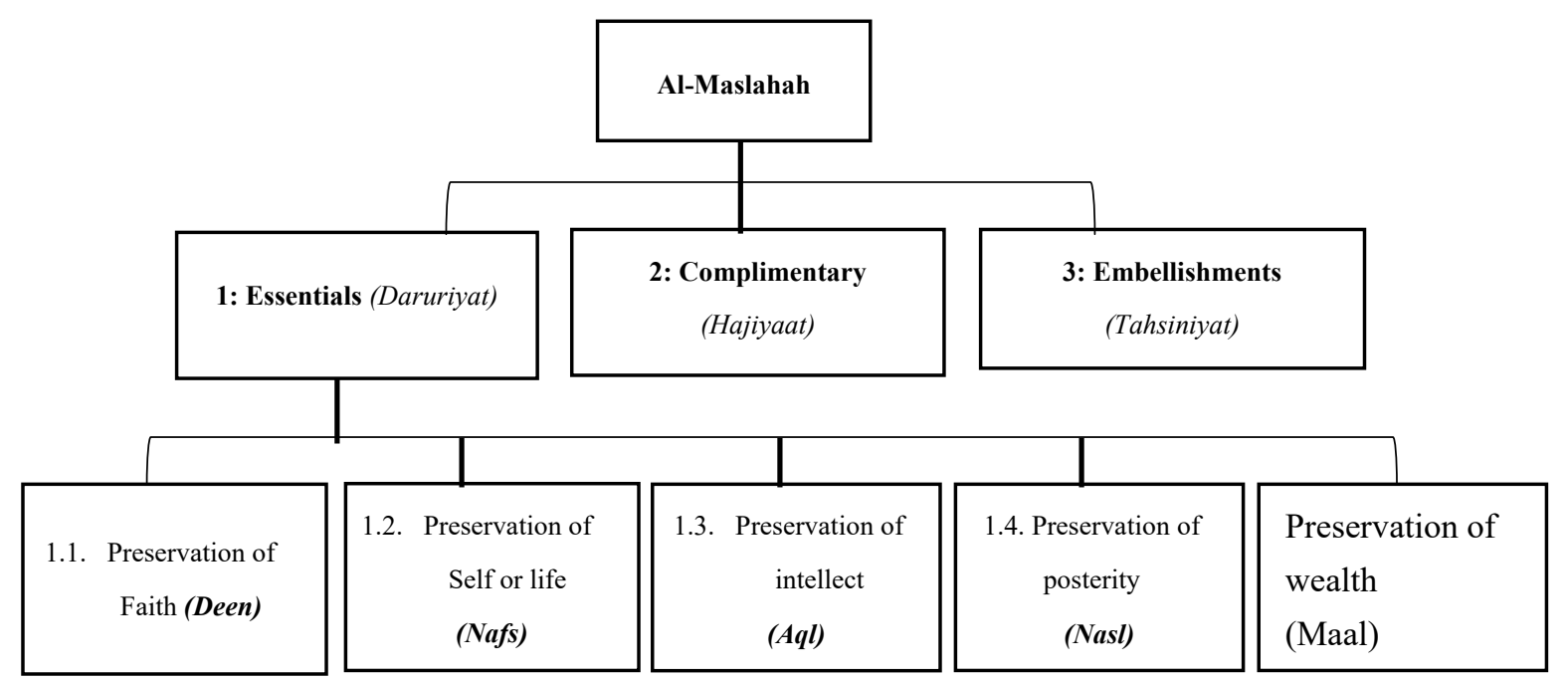

Figure 2. Al-Ghazali's Theoretical Framework of Maqasid al-Shariah (Yusof et al., 2015)

\section{1: Essentials}

The essential are those principles of Shariah which if neglected, would lead to the total collapse of the society.

\section{2: Complimentary}

The complimentary are those items which supplement the essentials, and it refers that the negligence of these items would not lead to the total disruption of the society, but would lead to certain hardship in the society. In other words, they are needed to alleviate hardness from the society.

\section{3: Embellishments}

The Embellishments are those items which are not compulsory in Shariah, but if they are performed, they will lead to the perfection of society.

The selected items from Table 7 are first testified as Islamic items based on the three principles of the theory of Maqaid-al-Shariah. And subsequently, the items are then incorporated to the respected economic, environmental, or social sustainability dimension of the GRI framework. The inclusion of new Islamic items selected from various indexes (see Table 7) is explained as under.

\subsection{Economic Sustainability Indicators}

1) Shariah screening during the investment

Selected from the study of Amran et al. (2017), (see Table 7) where it was used as an item to measure governance in the Islamic banking. In line with the theory of Maqasid-al-Shariah, this study ponders that Shariah screening during the investment falls under the category of essential and subcategory preservation of faith. It is because Islam prohibits haram business, and the investment in haram businesses as well. Therefore, it is necessary for the Shariah committee of the Islamic banks to report about Shariah screening during the investment in their subjected report. Performing and reporting on this item will increase the stakeholder's confidence in the Islamic banks. The increased stakeholder's confidence will ultimately lead the bank towards generating more funds. Which ultimately will increase its economic sustainability. Against this background, this item is integrated into the economic sustainability dimension of the transformed Global reporting Initiatives (GRI) framework as shown in Table 8 below.

\section{2) Allocation of profit based on Shariah principles}

Selected from the index of Amran et al. (2017), (see Table 7) the allocation of profit based on Shariah principles falls under the category of essentials and subcategory preservation of maal. Because it is essential for the Islamic banks to distribute profit with full justice to all depositors, and in the process to protect their wealth as well. The commitment of such act will increase the confidence of Islamic bank's client which may increase deposits. Accordingly, it will improve the economic sustainability of Islamic banks. And hence this item is integrated into the economic sustainability dimension of the transformed Global reporting Initiatives GRI framework as shown in Table 8 below. 


\section{3) Zakat payment}

Selected from the index of Haniffa and Hudaib (2007), zakat payment falls under the category of essentials and subcategory preservation of faith according to the theory of Maqasid Al-Shariah. Because paying zakat is compulsory (essential) in Islam. And, the commitment of it preserves the Muslim's faith as well. Paying zakat will improve the goodwill of the bank, and efficient goodwill will allow the bank to generate more fund. And accordingly, it will affect the economic sustainability of Islamic banks in a positive direction.

4) Qardh-e-Hassan / Benevolent fund

Selected from the index of Platonova et al. (2016), Qardh-e-Hassan it is categorized as a complimentary item in the essentials category of preservation of life, and preservation of posterity. Because if the Islamic banks allow interests free loans to their trusted customers, it will remove hardship from the society. And will let the people in assisting their life and family. Paying Qardh-e-Hassan will improve the goodwill of bank, and efficient goodwill will allow the bank to generate more fund. And accordingly, it will affect the economic sustainability of Islamic banks in a positive direction.

5) Charity - Sadaqah - Waqaf

Selected from Aribi and Gao (2011), index. Charity is confined to the category of embellishment. Because, paying charity is not compulsory in Shariah, but if the Islamic banks pay it, it will help the banks in its positive image building in its Islamic customers' mind. And as a result, the bank can attain more funds from various stakeholders. Which will ultimately affect the economic sustainability of banks positively.

6) Disclosure of earnings prohibited by Shariah

Selected from Maali et al. (2006), the disclosure of earning prohibited by Shariah falls under the complimentary item to the preservation of faith, preservation of self, and to the preservation of wealth. Because, it will reinstate the confidence of customers on their Islamic bank from faith, life and wealth point of view. The Islamic banks must design control systems to avoid the recurrence of such transaction. And forward any such gain to charity funds. This will increase customer's confidence in Islamic banks. Increased confidence will attain more deposits, and more deposits will improve economic sustainability of the Islamic banks. Accordingly, this item is placed in the economic sustainability dimension.

\subsection{Environmental Sustainability Indicators}

7) Compliance with Islamic laws for environment

Consistent with Haniffa et al. (2004), the compliance with Islamic laws for the environment is categorized as the essential and subcategory preservation of life and preservation of posterity. Because it is compulsory for the Islamic banks to abide Islamic laws for the green environment to assist the life and coming generations. Such as controlling air pollution, water pollution, and energy restoration for the coming generations. Performing such actions will increase the environmental sustainability of Islamic banks.

\subsection{Social Sustainability Indicators}

8) Islamic training and education to staff

Nominated from the index of Mallin et al. (2014), Islamic training and education are categorized as the complimentary item to the preservation of intellect under the category of essentials. The Islamic banks by providing Islamic training and education to their staff would comply with the decent labour work practices in the society. And ultimately it will positively affect the social sustainability of Islamic banks. Therefore, this item is integrated into the social sustainability dimension of the GRI model presented below in Table 8 .

\section{9) Sponsoring pilgrimage}

Taken from the index of Mallin et al. (2014), sponsoring pilgrimage facility by the Islamic banks is categories as the embellishment. Because providing such service is not compulsory is Shariah. However, by providing such facility, the Islamic banks will help in promoting Shariah principles in the society, which will affect its social sustainability positively.

\section{0) Scholarships}

Dusuki and Abdullah (2007), providing scholarships are categorized as the complimentary item to the preservation of intellect under the main category of essential. The Islamic banks must design a framework of granting scholarships for the Islamic Fiqh studies. In the manner, the Islamic banks will assist the people from society in the process of spreading and preserving the Islamic principles. 
11) Products and Services labelling (approved by the Shariah Committee)

Dusuki and Abdullah (2007), the product and services labelling approval from Shariah committee are categorized as the essential under the subcategory of preservation of the faith. Because in Islam it is obligatory to provide accurate information about the product or services before business. Incorporating. The approval of product and service labelling by Shariah committee will ensure Islamic values and will avoid any conflict in the society. This study by using the theory of Maqasid Al-Shariah as a benchmark for testifying any CSR item as an Islamic item will open a new line of inquiry. And it may lead to the process of incorporating many new items to the proposed framework in future. And in the process, this study may serve as a launching pad in the process of creating an international standards corporate sustainability measurement framework for the Islamic banking industry. The proposed sustainability measurement framework for the Islamic banks is presented in Table 8 below.

Table 8. Modified global reporting Initiatives framework for the financial services sector

\begin{tabular}{|c|c|}
\hline Aspect & $\begin{array}{l}\text { Parameters for Measurement of an Individual Items } \\
\text { Fully-Reported }=(02), \text { Partially-Reported }=(01), \text { No-Reporting }=(0)\end{array}$ \\
\hline \multicolumn{2}{|c|}{ 1). General Standards Disclosures (Integrated Strategies) } \\
\hline $\begin{array}{l}\text { 1. Strategy and } \\
\text { analysis }\end{array}$ & $\begin{array}{l}\mathrm{CEO} / \text { Chairman's statement with its relevance to sustainability, key events, and achievements regarding } \\
\text { sustainability during the reporting period. }\end{array}$ \\
\hline $\begin{array}{l}\text { 2. Organization } \\
\text { profile }\end{array}$ & Organizational chart including name, location, and countries of operations \\
\hline $\begin{array}{l}\text { 3. Identified material } \\
\text { aspect and boundaries }\end{array}$ & $\begin{array}{l}\text { Joint ventures, subsidiaries, Consolidated statements, data measurement techniques, significant changes from } \\
\text { previous reporting period }\end{array}$ \\
\hline $\begin{array}{l}\text { 4. Stakeholder } \\
\text { engagement }\end{array}$ & List of stakeholders group engaged by the organization \\
\hline Report profile & Reporting period (fiscal or calendar) reporting cycle (annual or biannual) \\
\hline Governance & Governance structure of the organization \\
\hline $\begin{array}{l}\text { 7. Ethics and } \\
\text { Integrity }\end{array}$ & Codes of conduct and codes of ethics for the organization \\
\hline
\end{tabular}

2). Economic Sustainability Indicators

8. Shariah screening

during the investment

9. Allocation of profit

based on Shariah Certification of distribution of profit/loses complying with Shariah in the Shariah Committee's report

principles

10. Economic

performance

11. Market presence

12. Indirect economic

impact

13. Procurement practices

14. Zakat payment

15. Qardh-e-Hassan

16. Charity - Sadaqah -

Waqaf

17. Disclosure of

earnings prohibited by Disclosure of earning prohibited by Shariah in the Shariah committee's report

Reporting about Shariah screening process for investment in the Shariah Committee's report

Direct economic value generated and distributed: Community investment

Reporting about minimum wages paid

Reporting about the investment made in infrastructural development and services supported/ commercial investment

Percentage of product and services purchased from local suppliers

Procedure and disclosure about total amount of zakat paid

Amount of Qardh-e-Hassan/ Benevolent fund paid

Reporting about total Charity - Sadaqah - Waqaf paid by the banks Shariah

\begin{tabular}{ll} 
3). Environmental Sustainability Indicators \\
\hline 18. Material & $\begin{array}{l}\text { Reporting about the total weight and volume of the material used, and percentage of material recycled. } \\
\text { Reporting about methodologies used for reduction of energy consumption required for heating, cooling and } \\
\text { steaming purposes of the banks }\end{array}$ \\
19. Energy &
\end{tabular}




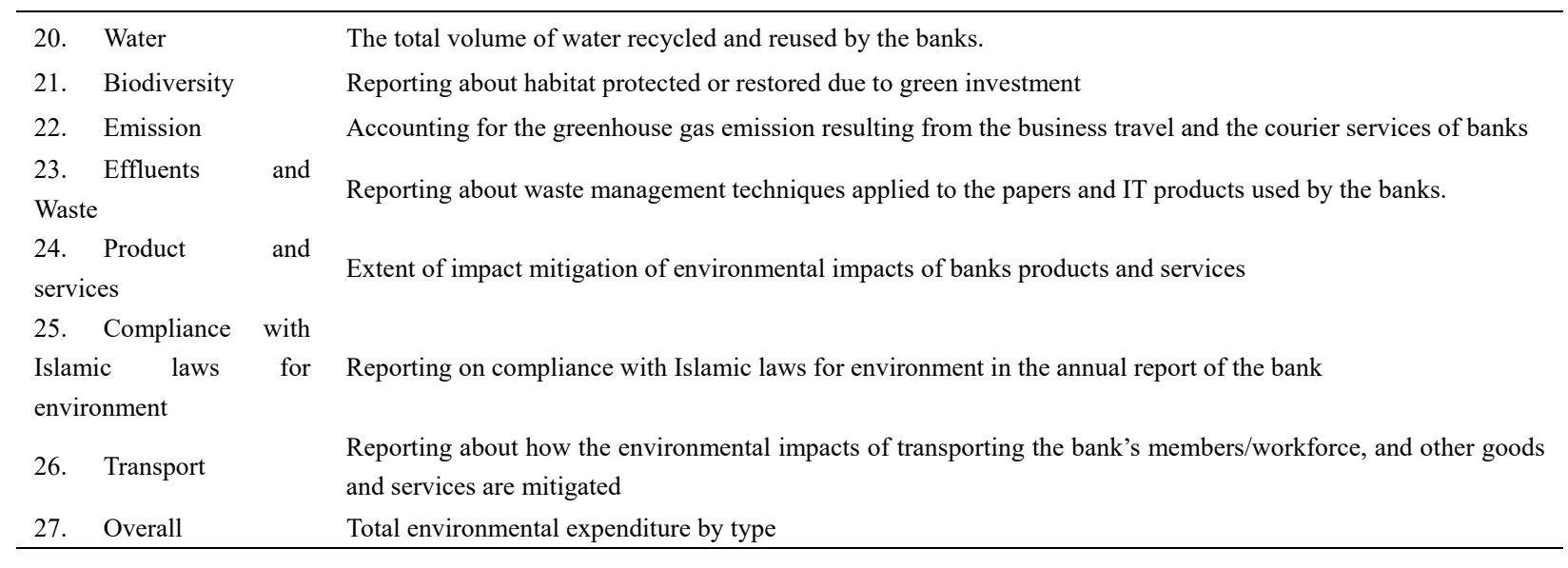

4). Social Sustainability Indicators

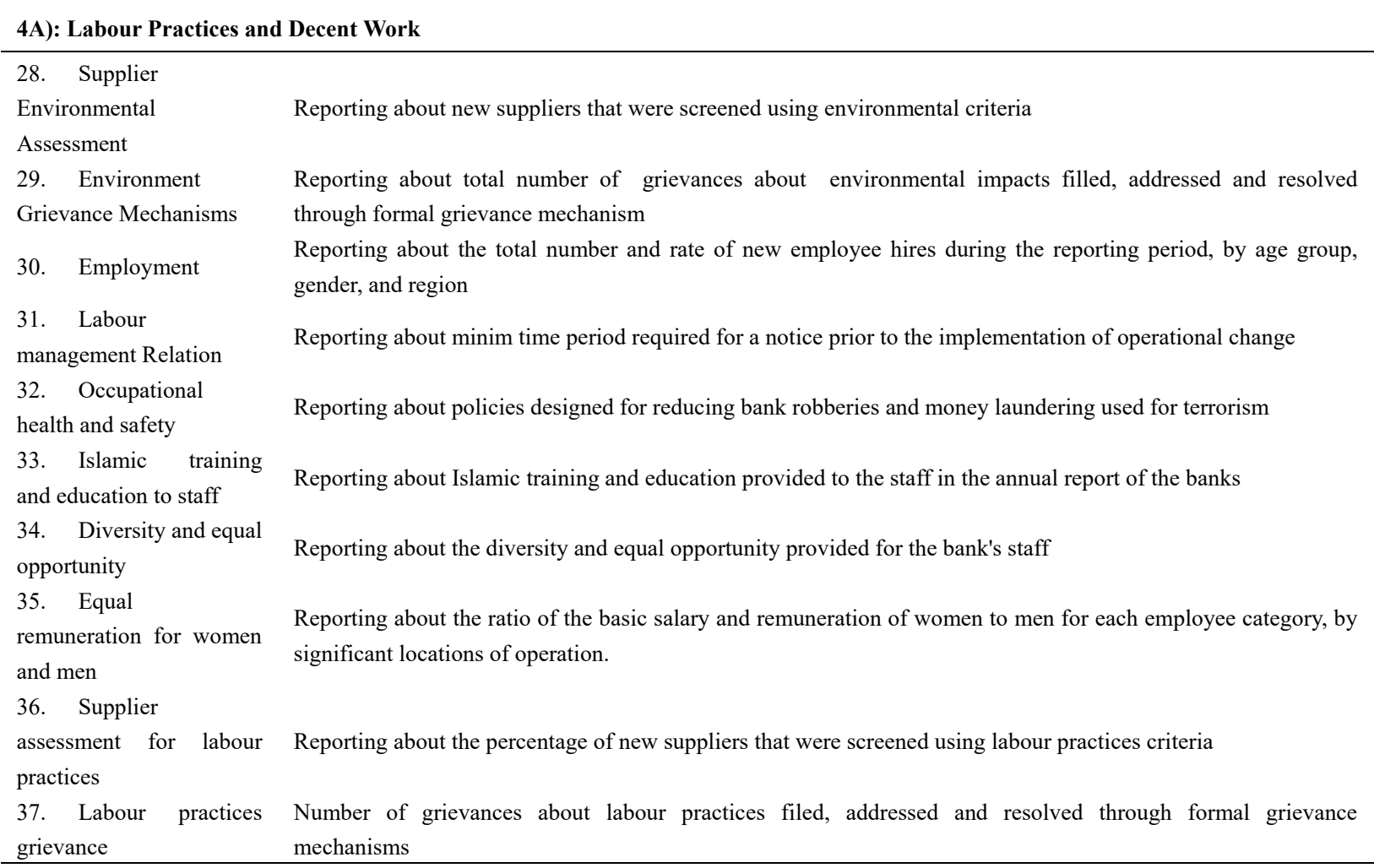

\section{B): Human Rights}

\begin{tabular}{|c|c|}
\hline 38. Investment & tal investment made by the banks to train its employees in human right policies and procedures. \\
\hline $\begin{array}{l}\text { 39. Non- } \\
\text { discrimination }\end{array}$ & Reporting about total number of incidents of discrimination and corrective actions taken by the bank \\
\hline $\begin{array}{l}40 . \quad \text { Freedom of } \\
\text { association and collective } \\
\text { bargaining }\end{array}$ & $\begin{array}{l}\text { Reporting about the measures taken by the banks to support right to exercise, freedom of association and } \\
\text { collective bargaining }\end{array}$ \\
\hline 41. Child labour & $\begin{array}{l}\text { Reporting about identification of child labour in the banking operations and supplier activities and effective } \\
\text { measures are taken }\end{array}$ \\
\hline $\begin{array}{l}\text { 42. Forced } \\
\text { compulsory labour }\end{array}$ & $\begin{array}{l}\text { Reporting about identification of forced and compulsory labour in the banking operations and supplier activities } \\
\text { and effective measures are taken }\end{array}$ \\
\hline 43. Security Practices & $\begin{array}{l}\text { Percentage of security personnel trained in the organization's human rights policies or procedures that are } \\
\text { relevant to operations }\end{array}$ \\
\hline Indigenous rights & Total number of incidents of violations involving rights of indigenous peoples and actions taken \\
\hline 45. Assessment & $\begin{array}{l}\text { Report the total number and percentage of operations that have been subject to human rights reviews or human } \\
\text { rights impact assessments, by country }\end{array}$ \\
\hline
\end{tabular}




\begin{tabular}{|c|c|}
\hline $\begin{array}{l}\text { 46. Supplier human } \\
\text { rights assessment } \\
\text { 47. Human rights } \\
\text { grievance mechanism }\end{array}$ & $\begin{array}{l}\text { Report the percentage of new suppliers that were screened using human rights criteria. } \\
\text { Number of grievances about human rights impacts filed, addressed and resolved through formal grievance } \\
\text { mechanisms }\end{array}$ \\
\hline \multicolumn{2}{|l|}{ 4C): Society } \\
\hline 48. Local communities & Initiatives to improve access to financial services for disadvantaged people \\
\hline 49. Anti-corruption & $\begin{array}{l}\text { Percentage of operations assessed for risks related to anti-corruption and action taken. Training provided on } \\
\text { anti-corruption policies and procedures }\end{array}$ \\
\hline 50. Pilgrimage & Reporting about the total number of subjects sent for pilgrimage \\
\hline 51. Scholarships & Reporting about the total sum of money spent for offering scholarships \\
\hline 52. Public policy & $\begin{array}{l}\text { Report the total monetary value of financial and in-kind political contributions made directly and indirectly by } \\
\text { the banks by country and recipient/beneficiary. }\end{array}$ \\
\hline $\begin{array}{l}\text { 53. Anti-competitive } \\
\text { behaviour }\end{array}$ & $\begin{array}{l}\text { Total number of legal actions for anti-competitive behaviour, anti-trust, and monopoly practices and their } \\
\text { outcomes }\end{array}$ \\
\hline 54. Compliance & $\begin{array}{l}\text { Monetary value of significant fines and total number of non-monetary sanctions for non-compliance with laws } \\
\text { and regulations }\end{array}$ \\
\hline $\begin{array}{l}55 . \quad \text { Supplier } \\
\text { assessment for impact on } \\
\text { society }\end{array}$ & ge of new suppliers that were screened using criteria for impacts on society \\
\hline $\begin{array}{l}\text { 56. Grievance } \\
\text { mechanism for impact on } \\
\text { society }\end{array}$ & $\begin{array}{l}\text { Number of grievances about impacts on society filed, addressed, and resolved through formal grievance } \\
\text { mechanisms }\end{array}$ \\
\hline \multicolumn{2}{|l|}{ 4D). Product Responsibility } \\
\hline $\begin{array}{l}\text { 57. Consumer health } \\
\text { and safety }\end{array}$ & $\begin{array}{l}\text { Reporting about the percentage of significant product and service categories for which health and safety } \\
\text { impacts are assessed for improvement }\end{array}$ \\
\hline $\begin{array}{l}\text { 58. Product and } \\
\text { service labelling }\end{array}$ & Policies for the fair design and sale of financial products and services \\
\hline $\begin{array}{l}\text { 59. Products and } \\
\text { Services labelling } \\
\text { (approved by the Shariah } \\
\text { Committee }\end{array}$ & Reporting about the approval about product and service labelling in the Shariah committee's report \\
\hline $\begin{array}{l}\text { 60. Marketing } \\
\text { communications }\end{array}$ & $\begin{array}{l}\text { Total number of incidents of non-compliance with regulations and voluntary codes concerning marketing } \\
\text { communications, including advertising, promotion, and sponsorship, by type of outcomes }\end{array}$ \\
\hline 61. Customer privacy & Reporting about the total number of substantiated complaints received concerning breaches of customer privacy \\
\hline 62. Compliance & $\begin{array}{l}\text { Monetary value of significant fines for non-compliance with laws and regulations concerning the provision and } \\
\text { use of product and services }\end{array}$ \\
\hline 63. Product Portfolio & Policies with specific social components applied to business lines \\
\hline 64. Audit & Coverage and frequency of audits to assess implementation of social policies and risk assessment procedures \\
\hline 65. Active Ownership & $\begin{array}{l}\text { Percentage and number of companies held in the bank's portfolio with which the bank has interacted on social } \\
\text { issues }\end{array}$ \\
\hline
\end{tabular}

Table 8 shows the transformation of the global reporting initiatives framework. In line with Mallin et al. (2014), this study combined two strands of sustainability reporting and practices i.e. "particular" reporting practices relating to Shariah compliance issues. And the "universal" reporting practices which are common both in Islamic and conventional banks such as community, employee, and customers. The universal reporting practices here refers to the default reporting items included in the general GRI framework. The new framework is composed of total 65 items which ensure sustainability measurement from both Islamic and conventional banks perspective. Furthermore, this study sets the standard for the inclusion of any new Islamic item into economic, environmental, and social sustainability dimensions. Accordingly, further sector specific (Islamic) items can be integrated into to GRI framework.

\subsection{Content Validity}

The parameter for measurement of individual items is shortlisted from different measurements techniques available in the Global Reporting Initiative's framework (GRI, 2016). While the parameters of measurement 
about the newly incorporated Islamic items is proposed by this study.

\subsubsection{Variables Operationalization}

\subsubsection{Independent Variables}

There are three independent variables used in the study as shown in Table 8. Namely, the variables are economic sustainability, environmental sustainability, and social sustainability.

\section{Economic sustainability}

The economic dimension of sustainability concerns the organization's impacts on the economic conditions of its stakeholders, and on economic systems at local, national, and global levels (GRI, 2016).

\section{Environmental sustainability}

The environmental dimension of sustainability concerns the organization's impact on living and non-living natural systems, including land, air, water and ecosystems (GRI, 2016).

\section{Social sustainability}

The social dimension of sustainability concerns the impacts the organization has on the social systems within which it operates (GRI, 2016).

\subsubsection{Operationalization of Independent Variables}

Content analysis technique is widely used in the corporate sustainability literature. In Malaysia, the majority of the past studies have used content analysis technique for measuring sustainability practices. Elijido-Ten (2016), used content analysis technique for environmental sustainability disclosures practices. Ghazali and Zahid (2015), used content analysis technique while developing environmental sustainability strategies for the construction companies in Malaysia. Mohamad Hafiz Bin Rosli (2015), used content analysis for measuring sustainability practices in the telecommunication sector of Malaysia. Aman et al. (2015), used content analysis for measuring sustainability practices of the public listed companies in Malaysia. Consistent with past studies, this study also proposing weighted method content analysis technique. The weighted method technique beyond the dummy codes of only 0-1 allows further weight in the quality of disclosure. Ameer and Othman (2012), while measuring sustainability practices of the top global corporations used the dummy codes of 0-4. Saleh et al. (2010), used the dummy codes of 1-3. Aktas et al. (2013), in line with the GRI guidelines, used the dummy code of 0-2 for measuring corporate sustainability practices of the nine selected public firms in Turkey. Evidence shows that sustainability reporting of the Islamic sector in Malaysia are low. Ousama and Fatima (2010), found that $80 \%$ of the items were undisclosed by the Shariah approved companies in Malaysia. Mohammed et al. (2009), found that the Shariah listed companies failed significantly for providing information on social and environmental sustainability themes. Nor and Asutay (2011), found that the awareness on the level of sustainability practices of the Islamic banks in Malaysia was very low. Consistent with the past literature and considering the low sustainability reporting of the Islamic banking industry in Malaysia this study proposed the dummy codes of 0-2 for measuring sustainability practicing and reporting of the Islamic banks in Malaysia. 0 represents the "absence" of an item. 1 represents the partial reporting of an item. While 2 represents the full reporting about a present item in the annual sustainability reports of the subjected Islamic banks.

\subsubsection{Formula of Measurement for Independent Variables}

Different formulas are used for measuring corporate social responsibility/corporate sustainability of firms in Malaysia. Amran et al. (2017), used the formula $\sum=\frac{d j}{N}$, where $d_{j}$ are the numbers of discousers, while $N$ meanst the maximum number of disclousers a bank could performe. Lim et al. (2008), used the Eq. 1 as shown below:

$$
\text { - Corporate Social Responsibility Level (CSRLEV) }=\frac{\text { Total disclosure of the company }}{\text { Total maximum disclosure score. }}
$$

Hassan et al. (2010), used the Eq. 2 for measuring social responsibility of the Islamic banks as shown below:-

$$
\text { Corporrate Social Responsibility Disclouser Index }(\mathrm{CDI})=\frac{\Sigma \mathrm{X}}{\mathrm{N}}
$$

Consistent with the past studies this study proposed Eq. 3 as shown below:-

$$
\text { - } \quad \text { Corporate Sustainability Index }(C S I)=\frac{\text { Number of disclosed items per section }}{\text { Total number of items per section }}
$$


Using the above formula the mean values of each section i.e. economic, environmental and social sustainability dimension will be obtained, which to be used later for the subsequent empirical testing.

\subsubsection{Operationalization of Moderating Variables}

\subsubsection{Shariah Supervisory Board Size}

It represents the total number of members available in the Shariah supervisory committee of the Islamic banks. Measurement of this variable will be in numbers which is consistent with (Amran et al., 2017).

\subsubsection{Director's Ownership}

It represents the direct interest of board of directors in the total ordinary shares of the Islamic banks. It can be measured using the following Eq. 4.

$$
\text { - Director' } \text { sownership }=\frac{\text { No of shares held by directors }}{\text { Total ordinary shares }}
$$

\subsubsection{Dependent Variables}

\subsubsection{Banks Financial Performance}

The dependent variable in this proposed study is the bank's financial performance. Which is calculated from three different perspective that is management, market and shareholder's perspective. Consistent with Platonova et al. (2016), and Mollah and Zaman (2015) this study used Return on Average Assets ROAA for measuring management performance of the Islamic banks in Malaysia. Consistent with Mollah and Zaman (2015) and Naushad and Malik (2015), this study used Tobin's Q ratio for measuring the market-based performance of the Islamic banks. Thirdly, in consistent with Platonova et al. (2016) this study used Return on Average Equity ROAE to measure the financial performance of the Islamic banking industry in Malaysia from shareholder's perspective.

\section{Conclusion and Future Research}

This paper is motivated by an effort to fill the gap by proposing a new sustainability measurement framework for the Islamic banking industry in Malaysia. And to illuminate its positive impact on the financial performance of the Islamic banks in Malaysia. In line with that, consistent with the objective number one this study out of theories and concepts proposed a three-dimensional sustainability measurement framework for the Islamic banking industry in compliance with Shariah principles (see Table 8). Against the second objective, this study with theoretical support irradiated the positive relationship between sustainability practicing and the financial performance of the Islamic banking (see section 2.7). In consonant to third objective, this study proposed efficient moderating variables for accelerating the positive relationship between sustainability practices and the financial performance of the Islamic banking industry. Therefore, it is anticipated that by adopting the proposed framework, sustainability practices of the Islamic banking industry will improved. It will holistically help Malaysia to control its negative climate change ratio by controlling greenhouse gas emission, energy preservation, and promoting green investment through the Islamic banking operations. It may serve societies by promoting decent labour work practices, human rights, and assisting local communities through the banking operations. Adopting the proposed framework will also improve the economic sustainability of Malaysian Islamic banks, which will ultimately help Malaysia in accomplishing its $11^{\text {th }}$ developmental plan in the quest of becoming a fully developed country by the year 2020 . The proposed framework can also be applied to the Islamic banking industries of the other Muslim countries. In a way, it lends credence to the idea of Islamic Reporting Initiative IRI's envisaged framework of building an international standard corporate sustainability measurement framework for the Islamic banking industry of the world. And finally, the study by using the theory of Maqasid Al-Shariah as a benchmark for testifying any sustainability items as an Islamic item and subsequently integrating it into the three dimensions of economic, environmental, and social sustainability will initiate a new line of inquiry. It may lead to the process of incorporating many new Islamic items into the proposed framework accordingly in future. The authors anticipate future studies to test the sustainability measurement framework in different Islamic banking countries. This will help to generalise the framework and shed more light on the current level of sustainability practices of Islamic banking industry across the world. Additionally, this study will also be useful for Academicians to conduct research and analysis in order to find out where future enhancements can be made to the subject of sustainability practices and its positive impact on the financial position of firms. 


\section{References}

Abduh, M. \& Idrees, Y. (2013). Determinants of Islamic banking profitability in Malaysia. Australian Journal of Basic and Applied Sciences, 7, 204-210.

Abdul Razak, D., Mohamed, M. O., \& Md Taib, F. (2008). The performance measures of Islamic banking based on the Maqasid framework. IIUM International Accounting Conference (INTAC IV) Putra Jaya Marroitt, 25 June 2008: International Islamic University Malaysia.

Ahmed Haji, A., \& Anum Mohd Ghazali, N. (2013). The quality and determinants of voluntary disclosures in annual reports of Shari'ah compliant companies in Malaysia. Humanomics, 29, 24-42.

Akhtar, M. F., Ali, K. \& Sadaqat, S. (201)1. Liquidity risk management: a comparative study between conventional and Islamic banks of Pakistan. Interdisciplinary Journal of Research in Business, 1, 35-44.

Aktas, R., Kayalidere, K. \& Kargin, M. (2013). Corporate sustainability reporting and analysis of sustainability reports in Turkey. International Journal of Economics and Finance, 5, 113.

Aliyu, S., Hassan, M. K., Mohd Yusof, R. \& Naiimi, N. (2016). Islamic Banking Sustainability: A Review of Literature and Directions for Future Research. Emerging Markets Finance and Trade.

Alsaadi, A., Ebrahim, M. S. \& Jaafar, A. (2017). Corporate Social Responsibility, Shariah-Compliance, and Earnings Quality. Journal of Financial Services Research, 51, 169-194.

Amalina Wan Abdullah, W., Percy, M. \& Stewart, J. (2013). Shari'ah disclosures in Malaysian and Indonesian Islamic banks: The Shari'ah governance system. Journal of Islamic Accounting and Business Research, 4, $100-131$

Aman, Z., Ismail, S., \& Bakar, N. S. (2015). Corporate sustainability reporting: Malaysian evidence. Proceeding of the 2nd International Conference on Management and Muamalah, 16th - 17th November 2015. Kolej Universiti Islam Antarabangsa Selangor, Bandar Seri Putra, 43000 Kajang, Selangor, MALAYSIA.

Ameer, R., \& Othman, R. (2012). Sustainability practices and corporate financial performance: A study based on the top global corporations. Journal of Business Ethics, 108, 61-79.

Amran, A., Fauzi, H., Purwanto, Y., Darus, F., Yusoff, H., Zain, M. M., Naim, D. M. A., \& Nejati, M. (2017). Social responsibility disclosure in Islamic banks: A comparative study of Indonesia and Malaysia. Journal of Financial Reporting and Accounting, 15.

Aribi, Z. A., \& Gao, S. S. (2011). Narrative disclosure of corporate social responsibility in Islamic financial institutions. Managerial Auditing Journal, 27, 199-222.

Asutay, M., \& Harningtyas, A. F. (2015). Developing Maqasid al-Shari'ah Index to evaluate social performance of Islamic Banks: A conceptual and empirical attempt. International Journal of Islamic Economics and Finance Studies, 1.

Bashir, A. H. M. (1999). Risk and profitability measures in Islamic banks: The case of two Sudanese banks. Islamic Economic Studies, 6, 1-24.

Belal, A. R., Abdelsalam, O., \& Nizamee, S. S. (2015). Ethical Reporting in Islami Bank Bangladesh Limited (1983-2010). Journal of Business Ethics, 129, 769-784.

Bowen, H. R. (2013). Social responsibilities of the businessman. University of Iowa Press.

Brown, B. J., Hanson, M. E., Liverman, D. M., \& Merideth, R. W. (1987). Global sustainability: toward definition. Environmental management, 11, 713-719.

Brown, H. S., De Jong, M., \& Lessidrenska, T. (2009). The rise of the Global Reporting Initiative: a case of institutional entrepreneurship. Environmental Politics, 18, 182-200.

Brundtland, G. (1987). Report of the World Commission on Environment and Development Our Common Future. United Nation: Oxford University Press..

Butlin, J. (1989). Our common future. By World commission on environment and development. London: Oxford University Press).

Campbell-Lendrum, D., \& Corvalán, C. (2007). Climate change and developing-country cities: implications for environmental health and equity. Journal of Urban Health, 84, 109-117. 
Carroll, A. B. (1979). A three-dimensional conceptual model of corporate performance. Academy of Management Review, 4, 497-505.

Carroll, A. B. (1983). Corporate social responsibility: Will industry respond to cutbacks in social program funding. Vital Speeches of the day, 49, 604-608.

Carroll, A. B. (1991). The pyramid of corporate social responsibility: Toward the moral management of organizational stakeholders. Business horizons, 34, 39-48.

Carroll, A., \& Buchholtz, A. (2014). Business and society: Ethics, sustainability, and stakeholder management, Nelson Education.

Chapra, M. U., Khan, S., \& Al Shaikh-Ali, A. (2008). The Islamic Vision of Development in the Light of Maqasid Al-Shariah Volume 15 of Occasional paper series. The international Institute of Islamic Thought: London . Washington

Čihák, M., \& Hesse, H. (2010). Islamic banks and financial stability: An empirical analysis. Journal of Financial Services Research, 38, 95-113.

Clarkson, M. E. (1995). A stakeholder framework for analyzing and evaluating corporate social performance. Academy of management review, 20, 92-117.

Cochran, P. L., \& Wood, R. A. (1984). Corporate social responsibility and financial performance. Academy of management Journal, 27, 42-56.

Colantonio, A. (2007). Social sustainability: An exploratory analysis of its definition, assessment methods metrics and tools. EIBURS Working Paper Series, 2007/01. Oxford Brooks University, Oxford Institute for Sustainable Development (OISD) - International Land Markets Group, Oxford, UK.

Cornell, B., \& Shapiro, A. C. (1987). Corporate stakeholders and corporate finance. Financial management, $5-14$.

Dahlsrud, A. (2008). How corporate social responsibility is defined: an analysis of 37 definitions. Corporate social responsibility and environmental management, 15, 1-13.

Davis, K. (1960). Can business afford to ignore social responsibilities? California management review, 2, 70-76.

Davis, K. (1973). The case for and against business assumption of social responsibilities. Academy of Management journal, 16, 312-322.

De Bakker, F. G., Groenewegen, P. \& Den Hond, F. (2005). A bibliometric analysis of 30 years of research and theory on corporate social responsibility and corporate social performance. Business \& Society, 44, 283-317.

Donaldson, T., \& Preston, L. E. (1995). The stakeholder theory of the corporation: Concepts, evidence, and implications. Academy of management Review, 20, 65-91.

Dusuki, A. W. (2005). Corporate social responsibility of Islamic banks in Malaysia: a synthesis of Islamic and stakeholders' perspectives. Asyraf Wajdi Dusuki.

Dusuki, A. W., \& Abdullah, N. I. (2007). Maqasid al-shari'ah, Maslahah and corporate social responsibility. The American Journal of Islamic Social Sciences (AJISS), 24, 25-45.

Dusuki, A. W., \& Yusof, T. F. M. T. M. (2016). The Pyramid of Corporate Social Responsibility Model: Empirical Evidence From Malaysian Stakeholder Persepective. Malaysian Accounting Review, 7.

Edward, F. R. (1984). Strategic Management: A stakeholder approach. Boston: Pitman.

Eilbirt, H., \& Parket, I. R. (1973). The practice of business: The current status of corporate social responsibility. Business Horizons, 16, 5-14.

El Moussawi, C., \& Obeid, H. (2011). Evaluating the productive efficiency of Islamic banking in GCC: A non-parametric approach. International Management Review, 7, 10-21.

Elijido-Ten, E. (2016). Can stakeholder theory add to our understanding of Malaysian environmental reporting attitudes? Malaysian Accounting Review, 8.

Elkington, J. (1994). Towards the sustainable corporation: Win-win-win business strategies for sustainable development. California management review, 36, 90-100.

Elkington, J. (1997). Cannibals with forks. The triple bottom line of 21st century. 
Epstein, E. M. (1989). Business ethics, corporate good citizenship and the corporate social policy process: A view from the United States. Journal of Business Ethics, 8, 583-595.

Farook, S., Kabir Hassan, M. \& Lanis, R. (2011). Determinants of corporate social responsibility disclosure: The case of Islamic banks. Journal of Islamic Accounting and Business Research, 2, 114-141.

Fitch, H. G. (1976). Achieving corporate social responsibility. Academy of management review, 1, 38-46.

Forum, W. E. (2017). The Global Risks Report 2017 The Global Competitiveness and Risks Team. World Economic Forum Geneva.

Forum, W. E. (2018). The Global Risks Report Committed to Improving the State of the World. World Economic Forum Geneva.

Frederick, W. C. (1960). The growing concern over business responsibility. California management review, 2 , 54-61.

Frederick, W. C. (1986). Toward CSR 3 : Why Ethical Analysis is Indispensable and Unavoidable in Corporate Affairs. California Management Review, 28, 126-141.

Frederick, W. C. (1998). Moving to CSR What to Packfor the Trip. Business \& Society, 37, 40-59.

Freeman, R. E. (1984). Strategic management: A stakeholder approach. 1984, Harpercollins College Div; First edition.

Friedman, M. (1970). The social responsibility of business is to increase its profits The New York Times Magazine 13 September.

Ghazali, Z., \& Zahid, M. (2015). Environmental sustainability: Carbon emission reduction strategies and reporting among Malaysian construction companies. Technology Management and Emerging Technologies (ISTMET), 2015 International Symposium on, 2015. IEEE, 417-421.

GRI. (2016). G4 Global Reporting Initiatives. Sustainability Reporting Guidelines: Reporting Principles and Standard Discloser. Sustsianbility Reporting Guidlines. Global Sustainability Standards Board.

Gunningham, N., Kagan, R. A. \& Thornton, D. (2004). Social license and environmental protection: why businesses go beyond compliance. Law \& Social Inquiry, 29, 307-341.

Hachicha, N., \& Amar, A. B. (2015). Islamic finance and economic growth: The Malaysian case. Islamic Economics: Theory, Policy and Social Justice: Volume 2.

Hameed, S., Wirman, A., Alrazi, B., Nazli, M., \& Pramono, S. (2004). Alternative disclosure and performance measures for Islamic banks. Proceedings: Conference on Administrative Sciences, King Fahd University of Petroleum and Minerals: Saudi Arabia, 2004.

Hamza, H. (2013). Sharia governance in Islamic banks: effectiveness and supervision model. International Journal of Islamic and Middle Eastern Finance and Management, 6, 226-237.

Hanif, M., Tariq, M., Tahir, A., \& Momeneen, W. (2011). Comparative performance study of conventional and Islamic banking in Pakistan. International Research Journal of Finance and Economics, 83, 62-72.

Hanif, M., Tariq, M., Tahir, A., \& Momeneen, W. U. (2012). Comparative performance study of conventional and islamic banking in Pakistan. International Research Journal of Finance \& Economics.

Haniffa, R. M. \& Cooke, T. E. (2005). The impact of culture and governance on corporate social reporting. Journal of accounting and public policy, 24, 391-430.

Haniffa, R., \& Hudaib, M. (2007). Exploring the ethical identity of Islamic banks via communication in annual reports. Journal of Business Ethics, 76, 97-116.

Haniffa, R., Hudaib, M. \& Mirza, A. M. (2004). Accounting Policy Choice within the Shariah Islamiiah Framework. Discussion Papers in Accountancy And Finance, SOBE, University Of Exeter, 2, 4-19.

Hashem, S., Giudici, P., \& Abedifar, P. (2016). Systemic Risk of Dual Banking Systems. International Journal of Central Banking, 7.

Hashim, F., Mahadi, N. D., \& Amran, A. (2015). Corporate Governance and Sustainability Practices in Islamic Financial Institutions: The Role of Country of Origin. Procedia Economics and Finance, 31, 36-43.

Hassan, A., \& Syafri Harahap, S. (2010). Exploring corporate social responsibility disclosure: the case of Islamic banks. International Journal of Islamic and Middle Eastern Finance and Management, 3, 203-227. 
Hassan, M. K., \& Bashir, A. H. M. (2003). Determinants of Islamic banking profitability. 10th ERF Annual Conference, Morocco.

Heald, M. (1957). Management's responsibility to society: The growth of an idea. Business History Review, 31, 375-384.

Ismal, R. (2010). Assessment of liquidity management in Islamic banking industry. International Journal of Islamic and Middle Eastern Finance and Management, 3, 147-167.

Jamali, D., \& Mirshak, R. (2007). Corporate social responsibility (CSR): Theory and practice in a developing country context. Journal of business ethics, 72, 243-262.

Jan, A., \& Marimuthu, M. (2015a). Bankruptcy and sustainability: A conceptual review on islamic banking industry. Global Business and Management Research, 7, 109.

Jan, A., \& Marimuthu, M. (2015b). Sustainability Profile of Islamic Banking Industry: Evidence from World Top Five Islamic Banking Countries. International Journal of Economics and Finance, 7, 125.

Jan, A., \& Marimuthu, M. (2016). Bankruptcy Profile of Foreign vs. Domestic Islamic Banks of Malaysia: A Post Crisis Period Analysis. International Journal of Economics and Financial Issues, 6.

Jan, A., Marimuthu, M., Shad, M. K., Ur-Rehman, H., Zahid, M., \& Jan, A. A. (2017). Bankruptcy profile of the Islamic and conventional banks in Malaysia: a post-crisis period analysis. Economic Change and Restructuring.

Jeucken, M. (2002). Banking and sustainability: Slow starters are gaining pace. Ethical Corporation Magazine, $11,44-48$.

Jeucken, M. H., \& Bouma, J. J. (1999). The Changing Environment of Banks (*). Greener Management International, 21-21.

Johnson, H. L. (1971). Business in contemporary society: Framework and issues, Wadsworth Pub. Co.

Jones, T. M. (1980). Corporate social responsibility revisited, redefined. California management review, 22, 59-67.

Khan, H. U. Z., Azizul Islam, M., Kayeser Fatima, J., \& Ahmed, K. (2011). Corporate sustainability reporting of major commercial banks in line with GRI: Bangladesh evidence. Social responsibility journal, 7, 347-362.

Kiliç, M. (2016). Online corporate social responsibility (CSR) disclosure in the banking industry: Evidence from Turkey. International Journal of Bank Marketing, 34, 550-569.

Kpmg, T. (2008). KPMG International survey of corporate responsibility reporting 2008. KPMG International Survey of Corporate Responsibility Reporting 2008. Amsterdam, The Netherlands: KPMG.

Lantos, G. P. (2001). The boundaries of strategic corporate social responsibility. Journal of Consumer Marketing, $18,595-632$.

Lehtonen, M. (2004). The environmental-social interface of sustainable development: capabilities, social capital, institutions. Ecological economics, 49, 199-214.

Lépineux, F. (2005). Stakeholder theory, society and social cohesion. Corporate Governance: The international journal of business in society, 5, 99-110.

Lim, Y. Z., Talha, M., Mohamed, J., \& Sallehhuddin, A. (2008). Corporate social responsibility disclosure and corporate governance in Malaysia. International Journal of Behavioural Accounting and Finance, 1, 67-89.

Maali, B., Casson, P., \& Napier, C. (2006). Social reporting by Islamic banks. Abacus, 42, 266-289.

Maclagan, P. (1999). Corporate social responsibility as a participative process. Business Ethics: A European Review, 8, 43-49.

Mallin, C., Farag, H., \& Ow-Yong, K. (2014). Corporate social responsibility and financial performance in Islamic banks. Journal of Economic Behavior \& Organization, 103, S21-S38.

Mcwilliams, A., \& Siegel, D. (2001). Corporate social responsibility: A theory of the firm perspective. Academy of management review, 26, 117-127.

Meutia, I. \& Febrianti, D. Islamic Social Reporting in Islamic Banking: Stakeholders Theory Perspective. SHS Web of Conferences, 34. https://doi.org/10.1051/shsconf/20173412001 
Mishra, S., \& Suar, D. (2010). Does corporate social responsibility influence firm performance of Indian companies? Journal of business Ethics, 95, 571-601.

Mohamad Hafiz Bin Rosli, A. P. D. J. B. S., \& Nuruu, A. B. F. (2015). Corporate Social Responsibility Disclosure (Csrd) In Malaysian Telecommunication Companies. South East Asia Journal of Contemporary Business, Economics and Law, 6(1).

Mohammed, R., Alwi, K., \& Jamil, C. Z. M. (2009). Sustainability Disclosure among Malaysian Sharie ah-Compliant listed Companies: Web Reporting. Issues in Social and Environmental Accounting, 3, 160-179.

Moir, L. 2001. What do we mean by corporate social responsibility? Corporate Governance: The international journal of business in society, 1, 16-22.

Mollah, S., \& Zaman, M. (2015). Shari'ah supervision, corporate governance and performance: Conventional vs. Islamic banks. Journal of Banking \& Finance, 58, 418-435.

Muda, M., Shaharuddin, A., \& Embaya, A. (2013). Comparative analysis of profitability determinants of domestic and foreign Islamic banks in Malaysia. International Journal of Economics and Financial Issues, 3, 559-569.

Naser, K., Al-Hussaini, A., Al-Kwari, D., \& Nuseibeh, R. (2006). Determinants of corporate social disclosure in developing countries: The case of Qatar. Advances in International Accounting, 19, 1-23.

Naushad, M., \& Malik, S. A. 2015. Corporate governance and bank performance: a study of selected banks in GCC region. Asian Social Science, 11, 226.

Nobanee, H., \& Ellili, N. (2016). Corporate sustainability disclosure in annual reports: Evidence from UAE banks: Islamic versus conventional. Renewable and Sustainable Energy Reviews, 55, 1336-1341.

Nor, S. M., \& Asutay, M. (2011). Re-considering CSR and sustainability identity of Islamic banks in Malaysia: An empirical analysis. International Conference on Islamic Economics and Finance, 1-17.

Nor, S. M., \& Hashim, N. A. CSR and Sustainability Dimension in Islamic Banking in Malaysia: A Management Insight. Proceedings of 26th International Business Conference, Imperial College, London, UK, 2014. $1-15$.

Numbeo. (2017). Quality of Life Index. NUMBEO.

Othman, R. \& Thani, A. M. 2010. Islamic social reporting of listed companies in Malaysia. The International Business \& Economics Research Journal, 9, 135.

Ousama, A. A., \& Fatima, A. (2010). Voluntary disclosure by Shariah approved companies: an exploratory study. Journal of Financial Reporting and Accounting, 8, 35-49.

Pezzey, J. (1992). Sustainable development concepts. World, 1, 45.

Platonova, E., Asutay, M., Dixon, R., \& Mohammad, S. (2016). The impact of corporate social responsibility disclosure on financial performance: Evidence from the GCC Islamic Banking Sector. Journal of Business Ethics, 1-21.

Preston, L. E., \& O'bannon, D. P. (1997). The corporate social-financial performance relationship: A typology and analysis. Business \& Society, 36, 419-429.

Preston, L. E., \& Post, J. (1975). Private management and public policy (Englewood Cliffs). Pretice: Hall.

Qureshi, M. A., \& Shaikh, M. (2012). Efficiency of Islamic and conventional banks in Pakistan: a non-parametric approach. International Journal of Business and Management, 7, 40.

Rahman, A. A., Asraf, M. F., \& Bakar, F. A. (2010). Corporate social reporting: A preliminary study of Bank Islam Malaysia Berhad (BIMB). Issues in Social and Environmental Accounting, 4, 18-39.

Rahman, S. (2011). Evaluation of definitions: ten dimensions of corporate social responsibility. World Review of Business Research, 1, 166-176.

Rashid, M., \& Nishat, A. 2009. Disparity of Performance Indicators of Islamic Banks: Study on Bangladesh. International Journal of Business and Management, 4, 52.

Richard, P. J., Devinney, T. M., Yip, G. S., \& Johnson, G. (2009). Measuring organizational performance: Towards methodological best practice. Journal of management, 35, 718-804. 
Rusydiana, A., \& Al Parisi, S. (2016). The Measurement of Islamic Bank Performance: A Study Using Maqasid Index and Profitability. Global Review of Islamic Economics and Business, 4, 1-14.

Said, D. (2013). Evaluating the Overall Technical Efficiency of Islamic Banks Operating in the MENA Region During the Financial Crisis. International Journal of Economics and Financial Issues, 3, 426-434.

Saleem, M., Khan, M. U., \& Siraj, S. (2013). The impact of interest based banking on socio-economic environment and its solution through Islamic finance concepts. International Journal of Scientific and Research Publications, 3, 1-8.

Saleh, A. S., \& Zeitun, R. (2006). Islamic banking performance in the Middle East: A case study of Jordan. Faculty of Commerce-Economics Working Papers, 157.

Saleh, M., Zulkifli, N., \& Muhamad, R. (2010). Corporate social responsibility disclosure and its relation on institutional ownership: Evidence from public listed companies in Malaysia. Managerial Auditing Journal, $25,591-613$.

Selvarajan, T., Ramamoorthy, N., Flood, P. C., Guthrie, J. P., Maccurtain, S., \& Liu, W. (2007). The role of human capital philosophy in promoting firm innovativeness and performance: Test of a causal model. The International Journal of Human Resource Management, 18, 1456-1470.

Sethi, S. P. (1975). Dimensions of corporate social performance: An analytical framework. California management review, 17, 58-64.

Singh, B. J. R. (2016). Corporate social responsibility in India. International Journal of Higher Education Research \& Development, 1 .

Sobhani, F. A., Zainuddin, Y., Amran, A., \& Baten, M. A. (2011). Corporate sustainability disclosure practices of selected banks: A trend analysis approach. African Journal of Business Management, 5, 2794.

Soltow, J. H., \& Heald, M. (1972). The Social Responsibilities of Business: Company and Community, 1900-1960.

Strand, R. (1983). A systems paradigm of organizational adaptations to the social environment. Academy of Management Review, 8, 90-96.

Suchman, M. C. (1995). Managing legitimacy: Strategic and institutional approaches. Academy of management review, 20, 571-610.

Sufian, F. (2007). The efficiency of Islamic banking industry in Malaysia: Foreign vs domestic banks. Humanomics, 23, 174-192.

Tuzzolino, F., \& Armandi, B. R. (1981). A need-hierarchy framework for assessing corporate social responsibility. Academy of management review, 6, 21-28.

Van Der Wiele, T., Kok, P., Mckenna, R., \& Brown, A. (2001). A corporate social responsibility audit within a quality management framework. Journal of Business Ethics, 31, 285-297.

Van Marrewijk, M. (2003). Concepts and definitions of CSR and corporate sustainability: Between agency and communion. Journal of business ethics, 44, 95-105.

Visser, W. (2008). The new era in Corporate Sustainability and Responsibility. CSR Inspiration Series.

Votaw, D. (1972). Genius becomes rare: A comment on the doctrine of social responsibility Pt. I. California management review, 15, 25-31.

Waddock, S. A., \& Graves, S. B. 1997. The corporate social performance-financial performance link. Strategic management journal, 303-319.

Walton, C. C. (1967). Corporate social responsibilities, Wadsworth Publishing Company.

Wartick, S. L., \& Cochran, P. L. (1985). The evolution of the corporate social performance model. Academy of management review, 10, 758-769.

Wasiuzzaman, S., \& Nair Gunasegavan, U. (2013). Comparative study of the performance of Islamic and conventional banks: The case of Malaysia. Humanomics, 29, 43-60.

Wernerfelt, B. (1984). A resource-based view of the firm. Strategic management journal, 5, 171-180.

Young, E. (2011-2012). World Islamic Banking Competitiveness Report 2011-12.

Young, E. (2013-2014). World Islamic Banking Competitiveness Report 2013-2014. 
Young, E. (2016). World Islamic Banking Competitiveness Report 2016. New realities New opportunities.

Yusof, S. A., Amin, R. M., Haneef, M. A., Muhammad, A., \& Oziev, G. (2015). The Integrated Development Index (I-Dex): A new comprehensive approach to measuring human development. Bloomsbury Qatar Foundation Doha.

Yusoff, H., \& Darus, F. (2014). Mitigation of climate change and prevention of pollution activities: environmental disclosure practice in Islamic financial institutions. Procedia-Social and Behavioral Sciences, 145, 195-203.

Zainal, D., \& Zainuddin, S. (2013). Corporate Social Responsibility Reporting in Malaysia: A Research Note. Journal of Accounting Perspectives, 6, 21-36.

Zenisek, T. J. (1979). Corporate social responsibility: A conceptualization based on organizational literature. Academy of management review, 4, 359-368.

\section{Copyrights}

Copyright for this article is retained by the author(s), with first publication rights granted to the journal.

This is an open-access article distributed under the terms and conditions of the Creative Commons Attribution license (http://creativecommons.org/licenses/by/4.0/). 